\title{
Proteomics analysis of regenerating amphibian limbs: changes during the onset of regeneration
}

\author{
MICHAEL W. KING*,1 , ANTON W. NEFF ${ }^{2}$ and ANTHONY L. MESCHER ${ }^{2}$ \\ Indiana University Center for Regenerative Biology and Medicine, ${ }^{1}$ Indiana University School of Medicine-Terre Haute and ${ }^{2}$ Indiana \\ University School of Medicine-Bloomington, IN, USA
}

\begin{abstract}
During amphibian epimorphic limb regeneration, local injury produces metabolic changes that lead to cellular dedifferentiation and formation of a blastema, but few details of these changes have been elucidated. Here we report the first global proteomic analysis of epimorphic regeneration comparing the profiles of abundant proteins in larval limbs of the anuran Xenopus laevis (stage 53) at the time of amputation (OdPA) and 3 days post-amputation when the regeneration blastema is developing (3dPA). We identified and quantified 1517 peptides, of which 1067 were identified with high peptide ID confidence. Of these 1067 proteins, 489 showed significant changes in quantity between the two groups. Taking into account identical peptides whose fold changes were within $20 \%$, and not including peptides whose fold changes were below the observed fold changes of peptides for the internal standard (chicken lysozyme), we were able to identify 145 peptides elevated in 3dPA relative to $0 \mathrm{dPA}$ and 220 peptides in $0 \mathrm{dPA}$ relative to 3dPA. In this report, we focus on those proteins that were elevated in the 3dPA tissue relative to OdPA. In this class were members of the annexin family (e.g. ANXA1, ANXA2, ANXA5) and the ANXA2-binding partner S100A10, which have important immunoregulatory roles in other systems and were also shown to be differentially expressed in stage 53 and $573 \mathrm{dPA}$ and $5 \mathrm{dPA}$ blastemas in our previous microarray studies. Besides elucidating the possible modulation of inflammation during amphibian limb regeneration, our proteomic study also provides insight into dedifferentiation by revealing up-regulation of proteins known to characterize many stem cells.
\end{abstract}

KEY WORDS: annexin, inflammation, limb, regeneration, Xenopus

\section{Introduction}

Among tetrapods, only urodeles such as salamanders and larval anurans have the ability to fully regenerate amputated limbs. The initial phase of regeneration includes wound closure by epidermal migration to form a wound epidermis and the reaction of deeper limb tissues to the amputation trauma. This reaction leads to the thorough remodeling of the tissues' extracellular matrices (ECM). In late larval anuran or adult urodele limbs this occurs concomitantly with histolysis, tissue and cellular dedifferentiation, and reversion of the cells to a mesenchymal state (Stocum, 2006). The mesenchymal cells proliferate to form the regeneration blastema out of which the missing portion of the limb develops in a process of epimorphic regeneration. Proliferation in the limb stump requires signaling from the apical wound epithelium and trophic factors from regenerating axons, but ECM breakdown, dedifferentiation, and renewed cell cycling all begin during the post-injury period of inflammation even in the absence of the wound epithelium and nerves (Tassava and Loyd, 1977; Tassava and Mescher, 1975).

Few studies of amphibian limb or fish fin regeneration have investigated details of the limb stump microenvironment in which ECM remodeling and cellular dedifferentiation are initiated. Gene expression during regeneration in larval limbs of Xenopus has been examined by subtractive hybridization (King et al., 2003) and by microarray analysis (Grow et al., 2006), and tail regenera-

\footnotetext{
Abbreviations used in this paper: ANXA, annexin; dPA, days post-amputation; ECM, extracellular matrix; IL-1, interleukin-1; LC/MS, liquid chromatography/mass spectroscopy; SOCS, suppressor of cytokine signaling; TGF- $\beta$, transforming growth factor-beta; TNF- $\alpha$, tumor necrosis factoralpha.
}

*Address correspondence to: Michael W. King. IUSM-TH, Room 135HH, Terre Haute, IN 47809, USA. Tel: +1-812-237-7646. Fax: +1-812-237-7646. e-mail: miking@iupui.edu - Web: http://themedicalbiochemistrypage.org/kingfact.html

Supplementary Material for this paper (additional methods data) is available at: http://dx.doi.org/10.1387/ijdb.082719mk

Accepted: 2 July 2008. Published online: 15 June 2009. Edited by: Christopher Wylie. 
tion in larval Xenopus has been the subject of similar molecular screens (Ishino et al., 2003; Tazaki et al., 2005). These and other studies have identified a large number of inflammatory and immune-related genes active during the early phase of regeneration. Expression of several genes with well-known roles in modulation of inflammation and immunity, including suppressor of cytokine signaling-3 (SOCS3), stress-inducible tumor rejection antigen gp96 ( TRA 1), fibrinogen-like protein 2(FGL2), myeloid differentiation factor 88 (MyD88), and complement $3(C 3)$, was found by qPCR to be strongly up-regulated locally within one day after amputation in Xenopus (Grow et al., 2006).

Possible roles for other specific components of innate immunity have also been uncovered during both limb and lens regeneration in adult newts. Both systems involve local synthesis of complement C3 and C5 (Kimura et al., 2003). Thrombin and tissue factor (which is involved in conversion of prothrombin to thrombin) have been shown to be important for dedifferentiation of muscle fibers in regenerating limbs (Kumar et al., 2004) and pigmented epithelial cells in lens regeneration (Imokawa et al., 2004). These and other aspects of immune involvement in regeneration have recently been reviewed (Godwin and Brockes, 2006; Mescher and Neff, 2006).

As another approach to investigate cellular activities in amputated limbs during the early phase of regeneration, we have undertaken proteomic analyses of larval Xenopus hindlimb stumps at premetamorphic stage 53 when essentially complete regeneration is possible. Proteomic data obtained from these regenerating limbs at this developmental stage can be compared directly with our previous molecular screens of limb regeneration. The major goals of the study were to examine changes in the proteome of the developing limb that are triggered by amputation and to gain further insight into the role of inflammatory activity occurring locally in the limb stump three days after amputation.

The results extend findings from our screens of gene activity during limb regeneration (King et al., 2003) identifying immunerelated genes expressed locally as a regeneration blastema is formed (Grow et al., 2006). Among the proteins we found to be most elevated in concentration after amputation are several members of the annexin family of highly conserved $\mathrm{Ca}^{2+}$ and phospholipid binding proteins important for many aspects of membrane organization and membrane traffic. The protein with one of the highest observed fold-changes (FC), annexin-1

\section{TABLE 1}

\section{PROTEIN CATEGORY, NUMBER OF SIGNIFICANT CHANGES AND EXHIBITED VARIABILITY (COEFFICIENT OF VARIATION) FOR EACH PROTEIN CATEGORY}

\begin{tabular}{ccccccc}
$\begin{array}{c}\text { Protein } \\
\text { Category }\end{array}$ & $\begin{array}{c}\text { Peptide ID } \\
\text { Confidence }\end{array}$ & $\begin{array}{c}\text { Multiple } \\
\text { Sequences }\end{array}$ & $\begin{array}{c}\text { Number } \\
\text { of Proteins }\end{array}$ & $\begin{array}{c}\text { Number } \\
\text { Significant } \\
\text { Changes }\end{array}$ & $\begin{array}{c}\text { Median \%CV } \\
\text { replicate }\end{array}$ & $\begin{array}{c}\text { Median \%cV } \\
\text { rep + sample }\end{array}$ \\
\hline 1 & HIGH & YES & 555 & 310 & 8.55 & 9.68 \\
2 & HIGH & NO & 512 & 179 & 14.54 & 15.81 \\
3 & LOW & YES & 27 & 7 & 17.86 & 19.08 \\
4 & LOW & NO & 423 & 114 & 20.68 & 24.61 \\
Overall & & & $\mathbf{1 5 1 7}$ & $\mathbf{6 1 0}$ & $\mathbf{1 2 . 6 2}$ & $\mathbf{1 4 . 4 4}$ \\
\hline
\end{tabular}

Proteins with best peptide having a confidence between $90-100 \%$ are assigned to the 'HIGH' category. Proteins with best peptide having a confidence between $75-89 \%$ are assigned to the 'LOW' category. The replicate median \% coefficient of variation (\%CV) is the standard deviation divided by the mean on a $\%$ scale.
(ANXA1), which mediates the anti-inflammatory activity of glucocorticoids (Wu et al., 1995) plays a major role in the resolution of inflammation (Perretti and Flower, 2004; Scannell et al., 2007). Since ANXA1 is upregulated in response to spinal cord injury (Liu et al., 2007) and in the regenerating salamander spinal cord (Monaghan et al., 2007) where it may play neuroprotective and anti-inflammatory roles (Solito et al., 2008) it has great interest for the field of regenerative biology. Other abundant proteins found to be strongly up-regulated after amputation include specific keratins with roles in cytoprotection and growth regulation during wound closure, some of which have been previously implicated in the control of blastema growth. The results highlight the importance of local inflammation and its resolution during the initial phase of limb regeneration, when dedifferentiation and early events of blastema formation are underway.

\section{Results}

\section{Statistically significant proteins in regenerating blastemas}

In order to identify proteins whose levels are higher in the regeneration-competent limb in response to amputation, we carried out mid-zeugopodial amputations of stage 53 hindlimbs, a stage at which gene expression during regeneration has been analyzed previously (King et al., 2003; Grow et al., 2006). We collected tissue at the site of amputation either immediately (0dPA) or 3-days post-amputation (3dPA) and subjected the samples to LC/MS analysis. By comparing the proteomes at these two times we were able to identify and quantify 1517 differentially expressed peptides. These proteins were then classified according to the confidence of the peptide identification as shown in Table 1.

A total of 489 peptides identified with a high confidence value (categories 1 and 2) were found to have statistically significant differences in expression at the two time points. Although we present data sets encompassing proteins higher in the 3dPA tissue and OdPA tissue, we focus on the proteins with higher levels in 3dPA tissue relative to 0dPA. Eliminating those with FC lower than that of the internal standard, chicken lysozyme, we were left with a total of 145 differentially expressed peptides listed in Table 2. Of the 145 individual peptides listed in Table 2, 136 have identifiable protein names and are listed first, sorted according to peptide identification category (i.e. category 1 then 2) followed by the peptides whose sequences were identified only as hypothetical, unknown or novel. Each peptide is listed with its annotated protein name, UniGene identifier and the accession number associated with full-length mRNA sequences. Although our focus was on proteins elevated in response to amputation and the onset of regeneration, shown in Table 3 are the 220 peptides identified with high confidence whose levels were higher in the limb amputation site at the time of amputation (0dPA) relative to 3dPA.

Several identical (as well as different) peptides representing the same protein were identified in our screen and these peptides are listed independently in Tables 2 and 3 . The peptides were listed independently because either the FC values for the identified peptides were different or the peptide ID confidence values placed the peptides in different categories (i.e. category 1 versus category 2$)$. Higgs et al. $(2005,2007)$ suggest that $\sim 10 \%$ reproducibility in quantitative measurements is possible using label- 
TABLE 2

PROTEINS EXPRESSED AT ELEVATED LEVELS IN 3dPA RELATIVE TO OdPA

\begin{tabular}{|c|c|c|c|c|c|c|}
\hline Protein Identification by Peptide(s) & Peptide & UniGene ID & Accession & FC & Category & Biological Process \\
\hline annexin 1 & GVDEGTIIDILTK & ANXA1 & BC053786 & 1.763 & 1 & $\mathrm{CC}, \mathrm{ST}$ \\
\hline keratin 12 & SLEEQLLQIR & KRT12 & BC108476 & 1.621 & 1 & $\mathrm{CG}, \mathrm{M}$ \\
\hline larval alpha globin & LFLSYPQTK & HBA & BC054259 & 1.619 & 1 & $\mathrm{~T}$ \\
\hline granulin & DVQCDDMYSCPDGQTCCR & GRN & BC048224 & 1.578 & 1 & $\mathrm{CC}, \mathrm{ST}$ \\
\hline apolipoprotein-A1 & LDTFGTNAMNLR & APOA1 & $\mathrm{BC} 077663$ & 1.504 & 1 & $\mathrm{~T}$ \\
\hline major vault protein & EAIPLDENEGIYVR & MVP & BC057708 & 1.446 & 1 & CG,M \\
\hline ferritin heavy chain & DEWSNTLEAMQAALQLEK & FTH1 & BC044961 & 1.428 & 1 & $\mathrm{~T}$ \\
\hline transthyretin & GIPAANLLVNVFR & TTR & AB026996 & 1.425 & 1 & $\mathrm{~T}$ \\
\hline phosphoserine aminotransferase 1 & VLFLQGGGSGQFSAIPLNLIGLK & PSAT1 & NM_001016582 & 1.410 & 1 & $\mathrm{M}, \mathrm{EP}$ \\
\hline myeloperoxidase, peroxidase $2^{\prime}$ & VGELLACLIGDQFR & MPO-A & AY069942 & 1.387 & 1 & $\mathrm{M}, \mathrm{EP}$ \\
\hline alpha globin larval-8 & IAPQASAIGAEALER & HBA-8 & BC135231 & 1.386 & 1 & $\mathrm{~T}$ \\
\hline fibrinogen gamma & IELEDWSNQK & FGG & BC054185 & 1.378 & 1 & PM \\
\hline polysomal ribonuclease 1 & DWLPLLLGSEMAAVLPAYR & PMR-1 & U68724 & 1.377 & 1 & PM \\
\hline transferrin, lactotransferrin & SNNEPYYNYAGAFK & TLTF & BC054950 & 1.355 & 1 & $\mathrm{~T}$ \\
\hline annexin 5 & VNDSLVEQDAQDLFK & ANXA5 & BC082506 & 1.339 & 1 & $\mathrm{CC}, \mathrm{ST}$ \\
\hline larval keratin & WTLLQEQGGQVK & LK-A & AB045599 & 1.339 & 1 & $\mathrm{CG}, \mathrm{M}$ \\
\hline transketolase & AVPTATVFYPSDAVSTEK & TKT & BC093574 & 1.332 & 1 & $\mathrm{M}, \mathrm{EP}$ \\
\hline B fibrinopeptide & GICDMPGEFWLGNEK & FGB & $\mathrm{BC} 084842$ & 1.329 & 1 & PM \\
\hline serine (or cysteine) proteinase inhibitor member $1 \mathrm{~d}$ & DVFSDLADLTGIAASR & SERPINA1D & BC054235 & 1.324 & 1 & PM \\
\hline keratin B1/B2 & DAELWFNQK & KRTB1/KRTB2 & X04805 & 1.322 & 1 & UNK \\
\hline thioredoxin & VDVDNASDVAQLCGVR & TXN & $\mathrm{BC} 084818$ & 1.321 & 1 & $\mathrm{M}, \mathrm{EP}$ \\
\hline interferon regulatory factor 2 binding protein 2 & MPWAMIWDFTEPVCR & IRF2BP2 & $\mathrm{BC} 081137$ & 1.309 & 1 & $\mathrm{RN}$ \\
\hline ferritin & LGVPQNGMGEYLFDK & FTN & $\mathrm{BC} 061303$ & 1.282 & 1 & $\mathrm{~T}$ \\
\hline ATPase, $\mathrm{Na}+\mathrm{K}+$ transporting, alpha 3 polypeptide & DVAGDASESALLK & ATP1A3 & BC043743 & 1.274 & 1 & $\mathrm{~T}$ \\
\hline profilin 2 & GTPSVWACTPGGVFSNITPAEINALVSPNR & PFN2 & $\mathrm{BC} 053770$ & 1.273 & 1 & CG,M \\
\hline lymphocyte cytosolic protein 1 & ISTSMPVLDLIDAIQPGCINYDLLK & LCP1 & BC056055 & 1.267 & 1 & $\mathrm{CC}, \mathrm{ST}$ \\
\hline alpha globin larval-6 & AAIASLWGK & HBA-6 & DQ224416 & 1.265 & 1 & $\mathrm{~T}$ \\
\hline fibrinogen A alpha polypeptide & NWPICSDEDWGPK & $\mathrm{FGA}$ & $\mathrm{BC} 041754$ & 1.264 & 1 & PM \\
\hline vimentin-1/vimentin-4 & QIQTLTCEIDAMK & VIM1/VIM4 & BC045233 & 1.260 & 1 & CG,M \\
\hline similar to Rho GDP-dissociation inhibitor 2 & SLLGDGPVVADPSAPNVTVTR & ARHGDIB & BC087424 & 1.259 & 1 & $\mathrm{CC}, \mathrm{ST}$ \\
\hline member RAS oncogene family, Rab43 & LQIWDTAGQER & RAB43 & BC097569 & 1.258 & 1 & $\mathrm{CC}, \mathrm{ST}$ \\
\hline beta globin & LLVVYPWTQR & HBB & BC078515 & 1.254 & 1 & $\mathrm{~T}$ \\
\hline serum albumin $B$ precursor & SCFTALGPDEDYVPPPVTDDTFHFDDK & ALBB & $\mathrm{BC} 081223$ & 1.252 & 1 & $\mathrm{~T}$ \\
\hline beta globin larva-1 & LGAAFTPQVQAAWEK & HBB-1 & BC078582 & 1.251 & 1 & $\mathrm{~T}$ \\
\hline keratin complex 2, basic, gene 5 & CNIDPLFEAYISSLR & KRT2-5 & BC121489 & 1.249 & 1 & $\mathrm{CG}, \mathrm{M}$ \\
\hline prohibitin & FDAGELITQR & PHB & $\mathrm{BC} 061380$ & 1.243 & 1 & $\mathrm{CC}, \mathrm{ST}$ \\
\hline transgelin 2 & YGIPASDLFQTVDLWEGK & TAGLN2 & BC072141 & 1.238 & 1 & UNK \\
\hline voltage-dependent anion channel 3 & LSLDTTFVPNTGK & VDAC3 & $\mathrm{BC} 071123$ & 1.234 & 1 & $\mathrm{~T}$ \\
\hline prosaposin (variant Gaucher disease) & LVSDVQDALR & PSAP & NM_001017285 & 1.220 & 1 & $\mathrm{CC}, \mathrm{ST}$ \\
\hline similar to apolipoprotein A-I & DAVSQLETSDLGK & APOA1 & BC041498 & 1.213 & 1 & $\mathrm{~T}$ \\
\hline fibronectin & YNVNVYQITEEGEK & FN1 & BC072841 & 1.213 & 1 & $\mathrm{CG}, \mathrm{M}$ \\
\hline annexin 2 , annexin II type 1 & GDLENAFLNLVQCIQNKPLYFADR & ANXA2 & BC042238 & 1.206 & 1 & $\mathrm{CC}, \mathrm{ST}$ \\
\hline cytoplasmic beta actin & DLYANTVLSGGTTMYPGIADR & АСТВ & $\mathrm{BC} 084121$ & 1.190 & 1 & $\mathrm{CG}, \mathrm{M}$ \\
\hline collagen, type I, alpha 1 & GPPGPSGSPGPQGFQGPPGEPGEPGSSGAMGPR & COL1A1 & BC049829 & 1.188 & 1 & $\mathrm{CG}, \mathrm{M}$ \\
\hline non-muscle myosin II heavy chain & ELESQIGELQEDLESER & NMMHC & $\mathrm{BC} 047253$ & 1.184 & 1 & $\mathrm{CG}, \mathrm{M}$ \\
\hline similar to Staphylococcal nuclease domain containing 1 & DTSGENIAESLVAEGLASR & SND1 & BC063211 & 1.182 & 1 & $\mathrm{RN}$ \\
\hline annexin 1 & GLGTDEDTLIEILASR & ANXA1 & BC053786 & 1.176 & 1 & $\mathrm{CC}, \mathrm{ST}$ \\
\hline annexin 2 , annexin II type 1 & GALSGNLETVMLGLIK & ANXA2 & BC042238 & 1.174 & 1 & $\mathrm{CC}, \mathrm{ST}$ \\
\hline transforming growth factor beta-induced $68 \mathrm{kDa}$ & QYTLLAPTNEAFEK & TGFB1i1 & BC121403 & 1.151 & 1 & $\mathrm{CC}, \mathrm{ST}$ \\
\hline keratin complex 2 , basic, gene 5 & LESGFQNLSIQTK & KRT2-5 & BC121489 & 1.148 & 1 & $\mathrm{CG}, \mathrm{M}$ \\
\hline collagen, type I, alpha 2 & GTPGESGAAGPFGPLGPR & COL1A2 & BC049829 & 1.147 & 1 & $\mathrm{CG}, \mathrm{M}$ \\
\hline $\begin{array}{l}\text { complement component } 1 \mathrm{q} \text { subcomponent binding } \\
\text { protein }\end{array}$ & AEENEPELVSTPNFVVEVLK & C1QBP & $\mathrm{BC} 056846$ & 1.146 & 1 & $\mathrm{IR}$ \\
\hline NM23/nucleoside diphosphate kinase & FQQASQDLLR & NM23NDK-A & BC079795 & 1.139 & 1 & $\mathrm{M}, \mathrm{EP}$ \\
\hline fetuin B & TEYIQFPEVASHLPTCPLIIEEK & FETUB & $\mathrm{BC} 078490$ & 1.139 & 1 & $\mathrm{IR}$ \\
\hline glutathione-S-transferase & QMASEPLPPELLEFLK & GST & BC072203 & 1.137 & 1 & $\mathrm{M}, \mathrm{EP}$ \\
\hline larval keratin & AGLEASLADTEGR & LK-A & AB045599 & 1.136 & 1 & $\mathrm{CG}, \mathrm{M}$ \\
\hline transforming growth factor beta-induced $68 \mathrm{kDa}$ & GCPAALPLSNIYETLGIVGAATTQLYSDR & TGFB1i1 & BC121403 & 1.134 & 1 & $\mathrm{CC}, \mathrm{ST}$ \\
\hline non-muscle myosin II heavy chain & IVGLDQVAGMGDTALPGAFK & NMMHC & $\mathrm{BC} 047253$ & 1.128 & 1 & $\mathrm{CG}, \mathrm{M}$ \\
\hline collagen, type I, alpha 1 & SAGISMPGPMGPMGPR & COL1A1 & BC049829 & 1.126 & 1 & $\mathrm{CG}, \mathrm{M}$ \\
\hline putative cathepsin $\mathrm{L}$ & LISLSEQNLVDCSR & CTSL & BC060335 & 1.123 & 1 & PM \\
\hline ribosomal protein $\mathrm{S} 19$ & ELAPYDENWFYTR & RPS19 & BC056505 & 1.121 & 1 & PM \\
\hline
\end{tabular}


TABLE 2 (continued)

PROTEINS EXPRESSED AT ELEVATED LEVELS IN 3dPA RELATIVE TO OdPA

\begin{tabular}{|c|c|c|c|c|c|c|}
\hline Protein Identification by Peptide(s) & Peptide & UniGene ID & Accession & FC & Category & Biological Process \\
\hline myosin regulatory light chain & ATSNVFAMFDQSQIQEFK & MRLC2 & CR760144 & 1.114 & 1 & CG,M \\
\hline moesin & IGFPWSEIR & MSN & BC121565 & 1.111 & 1 & CG,M \\
\hline annexin 1 & TPAEFDAYELK & ANXA1 & BC053786 & 1.099 & 1 & CC,ST \\
\hline $\begin{array}{l}\text { similar to myosin light chain } 1 \text {, skeletal muscle isoform } \\
\text { A1 catalytic }\end{array}$ & TLEFEQFLPMLQAIAK & $\mathrm{MLC1F} / 3 \mathrm{~F}$ & BC092347 & 1.099 & 1 & CG,M \\
\hline tropomyosin & IQLVEEELDR & TPM & BC070998 & 1.093 & 1 & $\mathrm{CG}, \mathrm{M}$ \\
\hline glyceraldehyde-3-phosphate dehydrogenase type $\mathrm{B}$ & B VPVPNVSVVDLTCR & GAPDHB & AF549496 & 1.090 & 1 & $\mathrm{M}, \mathrm{EP}$ \\
\hline lumican & IDLPQDMYSCLR & LUM & BC054282 & 1.087 & 1 & CG,M \\
\hline phosphoserine aminotransferase 1 & DVLNFGAGPAK & PSAT1 & NM_001016582 & 2.630 & 2 & M,EP \\
\hline keratin & TVIEEVVDGK & KRT1-2 & BC045031 & 1.822 & 2 & CG,M \\
\hline $\begin{array}{l}\text { SWI/SNF related, matrix associated, actin- } \\
\text { dependent regulator of chromatin, subfamily d, } \\
\text { member } 1\end{array}$ & TQMNSFLLSTASQQEIAALDNK & SMARCD1 & CR926205 & 1.760 & 2 & RN \\
\hline procyclic acid repeat protein & EELGFLPSYSASQLK & PARP & BC110778 & 1.738 & 2 & UNK \\
\hline solute carrier family 26 , member 6 & VDTLIELKK & SLC26A6 & BC097666 & 1.682 & 2 & $\mathrm{~T}$ \\
\hline alkylated DNA repair protein alkB homolog 5 & SVLLPKQRR & ALKBH5 & BC073226 & 1.656 & 2 & UNK \\
\hline $\begin{array}{l}\text { novel protein similar to PTPRF interacting protein, } \\
\text { binding protein } 2\end{array}$ & VTSQLHHLSIK & PPFIBP2 & CR926392 & 1.610 & 2 & CG,M \\
\hline slingshot-related protein & EETERIIKLKLRDI & SSH & BC080117 & 1.604 & 2 & CG,M \\
\hline calcium-binding protein p26olf & DGCADTMTYQEFEDFMK & LOC443554 & AB063625 & 1.603 & 2 & UNK \\
\hline ATPase, $\mathrm{H}+$ transporting, $\mathrm{V} 0$ subunit $\mathrm{B}$ & LAIVSQNLQK & ATP6V0B & BC090362 & 1.566 & 2 & $\mathrm{~T}$ \\
\hline neurofilament 3 & EYQDLLNVK & NEF3 & BC118832 & 1.539 & 2 & $\mathrm{CG}, \mathrm{M}$ \\
\hline beta globin & LLVVYPWTQR & HBB & BC078515 & 1.524 & 2 & $\mathrm{~T}$ \\
\hline amyloid-beta-like protein A precursor & QLSGKDIITDVK & APLP2 A & AJ608932 & 1.503 & 2 & $\mathrm{CC}, \mathrm{ST}$ \\
\hline aldolase $\mathrm{A}$ & GVVPLAGTNGETTTQGLDGLSER & ALDOA & BC106622 & 1.503 & 2 & M,EP \\
\hline manganese superoxide dismutase & MRCVPALAYSFCK & SOD2 & AY362041 & 1.479 & 2 & $\mathrm{CP}$ \\
\hline glucokinase & HEDIDKGILLNWTK & GCK & X93494 & 1.416 & 2 & $\mathrm{M}, \mathrm{EP}$ \\
\hline keratin 17 & YCMQLSQIQGLIGNVEAQLADLR & KRT17 & BC074309 & 1.410 & 2 & CG,M \\
\hline DNA repair and recombination protein 54 & MTAEPMSESK & RAD54 & BC094402 & 1.407 & 2 & RN \\
\hline fibrinogen $\mathrm{A}$ alpha polypeptide & NWPICSDEDWGPK & FGA & BC041754 & 1.392 & 2 & PM \\
\hline cofilin & EDLTLQQLAEK & CFL1 & BC045044 & 1.389 & 2 & $\mathrm{CG}, \mathrm{M}$ \\
\hline IkappaB kinase complex-associated protein & ANLSLLGGAKK & IKBKAP & BC110776 & 1.369 & 2 & CC,ST \\
\hline galectin VIIa & VPYDLPLPSGVVPR & LGALS7 & AB080020 & 1.358 & 2 & CG,M \\
\hline integrin alpha $V$ subunit & YETDGPMDCTSDVEINPLNVK & ITGAV & U92006 & 1.357 & 2 & CC,ST \\
\hline elastase 2 & VNQVFENGFNPLTLENDIVILK & ELA2 & $\mathrm{BC} 106661$ & 1.351 & 2 & PM \\
\hline SP22 & DVMLCPDTSLEEAR & PARK7 & AF394958 & 1.336 & 2 & RN \\
\hline aldehyde dehydrogenase 7 member $A 1$ & CEGGTVVCGGK & ALDH7A1 & NM_001016377 & 1.308 & 2 & M,EP \\
\hline $\begin{array}{l}\text { proteasome (prosome, macropain) } 26 \mathrm{~S} \text { subunit, non- } \\
\text { ATPase, } 12\end{array}$ & DPNDLLNDWSQK & PSMD12 & CR848271 & 1.297 & 2 & PM \\
\hline phospholipase D & VAVNPPDSPIR & PLD3 & BC059981 & 1.295 & 2 & M,EP \\
\hline annexin 7 & AAPNFDALSDAEK & ANXA7 & U16365 & 1.293 & 2 & $\mathrm{~T}$ \\
\hline glucose-6-phosphate isomerase & ELQASGLTGEALDK & GPI & BC073315 & 1.287 & 2 & $\mathrm{M}, \mathrm{EP}$ \\
\hline ribosomal protein L19 & VWLDPNETNEIANANSR & RPL19 & BC041546 & 1.286 & 2 & PM \\
\hline kinesin light chain 4 & LVMQGLEALR & KLC4 & BC043636 & 1.277 & 2 & $\mathrm{~T}$ \\
\hline $\begin{array}{l}\text { ATP-dependent chromatin remodeling DEXH-box } \\
\text { protein, BRG1 }\end{array}$ & AIEEGTLEEIEEEVR & SMARCA4 & AY762376 & 1.277 & 2 & $\mathrm{RN}$ \\
\hline ribosomal protein S11 & CPFTGNVSIR & RPS11 & X78805 & 1.269 & 2 & PM \\
\hline calpactin I (annexin II) light chain $\mathrm{p} 11$ subunit & LLDSEFSEFLK & S100A10 & BC088081 & 1.263 & 2 & CC,ST \\
\hline calpain 2 & NFPETFWMNPQYMIK & CAPN2 & BC063733 & 1.260 & 2 & PM \\
\hline phosphatidylserine decarboxylase & AVYSRAPTR & PISD & BC074595 & 1.260 & 2 & $\mathrm{M}, \mathrm{EP}$ \\
\hline gelatinase B, matrixmetalloproteinase 9 & ILNYSPDLDPEVIDDAFAR & MMP9 & AF072455 & 1.251 & 2 & PM \\
\hline dipeptidylpeptidase 3 & TVADQMYSLEPAER & DPP3 & BC060495 & 1.250 & 2 & PM \\
\hline similar to matrix metalloproteinase 13 (collagenase 3 ) & AFGVWSNVTPLQFTK & MMP13 & BC046939 & 1.250 & 2 & PM \\
\hline $\begin{array}{l}\text { similar to complement component } 1 \text {, q subcomponent } \\
\text { binding protein }\end{array}$ & EVSFQPTGDTEWK & C1QBP & BC056846 & 1.249 & 2 & IR \\
\hline ubiquitin specific protease 33 & CLMDVLHEELK & UCHL1 & NM_00106228 & 1.237 & 2 & PM \\
\hline c-met/hepatocyte growth factor receptor & IYVLNENLTK & MET & AB027411 & 1.231 & 2 & CC,ST \\
\hline non-muscle myosin smooth muscle & NMDPLNDNVTALLNQSSDK & NMMHC & BC084652 & 1.229 & 2 & $\mathrm{CG}, \mathrm{M}$ \\
\hline trypsin & INQVFENGFNPMNLENDIVILK & PRSS1 & BC108835 & 1.227 & 2 & PM \\
\hline similar to cytochrome P450 3A70 & TVLSPTFTSGKLK & CYP3A70 & BC084827 & 1.225 & 2 & $\mathrm{M}, \mathrm{EP}$ \\
\hline $\begin{array}{l}\text { enoyl Coenzyme A hydratase, short chain, } 1 \text {, } \\
\text { mitochondrial }\end{array}$ & AEFGQPEILLGTIPGAGGTQR & ECHS1 & BC074535 & 1.208 & 2 & M.EP \\
\hline prosaposin & LVSDVQDALR & PSAP & NM_001017285 & 1.206 & 2 & CC,ST \\
\hline programmed cell death 4 & MEIETPSDINANVESDSELSGVEQNR & PDCD4 & BC082619 & 1.202 & 2 & A \\
\hline
\end{tabular}


TABLE 2 (continued)

PROTEINS EXPRESSED AT ELEVATED LEVELS IN 3dPA RELATIVE TO OdPA

\begin{tabular}{|c|c|c|c|c|c|c|}
\hline Protein Identification by Peptide(s) & Peptide & UniGene ID & Accession & FC & Category & Biological Process \\
\hline DEAH (Asp-Glu-Ala-His) box polypeptide 9 & ELDALDSNDELTPLGR & DHX9 & CR760714 & 1.196 & 2 & RN \\
\hline lamin $A / C$ & MQQQLDEYQELLDIK & LMNA & NM_001083354 & 1.192 & 2 & $\mathrm{CG}, \mathrm{M}$ \\
\hline similar to cathepsin B & ILGWGVENGTPYWLCANSWNTDWGDNGFFK & CTSB & BC063365 & 1.187 & 2 & PM \\
\hline adult keratin & MSYSCVK & AK-B & AB045601 & 1.172 & 2 & $\mathrm{CG}, \mathrm{M}$ \\
\hline prosaposin & TGDICNDCTTLISDVQDALR & PSAP & NM_001017285 & 1.171 & 2 & $\mathrm{CC}, \mathrm{ST}$ \\
\hline suppressor of cytokine signaling- 6 & YLLSLSFR & socs6 & $\mathrm{BC} 077367$ & 1.154 & 2 & $\mathrm{CC}, \mathrm{ST}$ \\
\hline guanine nucleotide-binding protein alpha- 14 subunit & VPTTGIIEYPFDLENIIFR & GNA14 & BC080940 & 1.149 & 2 & $\mathrm{CC}, \mathrm{ST}$ \\
\hline methionyl aminopeptidase 2 & SQTDPPSIPISELYPSGVFPK & METAP2 & NM_00106115 & 1.146 & 2 & PM \\
\hline transaldolase 1 & NLGGSEEEQINNIMDK & TALDO1 & $\mathrm{BC} 084118$ & 1.144 & 2 & M,EP \\
\hline copine & DIVQFVPFR & CPNE1 & BC106238 & 1.144 & 2 & $\mathrm{~T}$ \\
\hline junction plakoglobin & LNTIPLFVQLLYSPVENIQR & JUP & BC094116 & 1.141 & 2 & $\mathrm{CC}, \mathrm{ST}$ \\
\hline collagen VI & QSVAFPLAFDLTEVSQAIEK & COL6A3 & BC089181 & 1.137 & 2 & $\mathrm{CG}, \mathrm{M}$ \\
\hline member RAS oncogene family, Rab33B & IQLWDTAGQER & RAB33B & $\mathrm{BC} 081311$ & 1.121 & 2 & $\mathrm{CC}, \mathrm{ST}$ \\
\hline Ras-related protein Rab & LQLWDTAGQER & RAB1A & BC118789 & 1.121 & 2 & $\mathrm{CC}, \mathrm{ST}$ \\
\hline ribosomal protein L13 & GFSLEELK & RPL13 & CR760720 & 1.119 & 2 & PM \\
\hline member RAS oncogene family, Rab43 & LQIWDTAGQER & RAB43 & BC097569 & 1.118 & 2 & $\mathrm{CC}, \mathrm{ST}$ \\
\hline suppressor of Ty, domain containing 1 & QPSSSGAVRPSSGPPTGATPK & SPT2D1 & BC121680 & 1.104 & 2 & RN \\
\hline Rab3 GTPase-activating protein catalytic subunit & ESPLNNDVLNAILFFLF & RAB3GAP1 & BC081089 & 1.101 & 2 & $\mathrm{CC}, \mathrm{ST}$ \\
\hline similar to adenylosuccinate synthetase & VVDLLAQDADIVCR & ADSS2 & CR761467 & 1.100 & 2 & $\mathrm{M}, \mathrm{EP}$ \\
\hline \multicolumn{7}{|l|}{ Novel, Hypothetic, or Unknown Proteins } \\
\hline & QNHVVVLDSR & MGC82459 & $\mathrm{BC} 077467$ & 1.721 & 2 & \\
\hline & MQSNSSLVPEK & MGC81344 & $\mathrm{BC} 076732$ & 1.645 & 2 & \\
\hline & ISVLESELASLR & MGC82812 & BC073542 & 1.484 & 2 & \\
\hline & QGILNILAAR & MGC80123 & $\mathrm{BC} 072800$ & 1.323 & 2 & \\
\hline & ILLSVGFSR & LOC548906 & NM_00106152 & 1.300 & 2 & \\
\hline & VSFMVTPSLFVDPLYGR & LOC398539 & BC076719 & 1.249 & 1 & \\
\hline & IGYNFDPISR & MGC:115035 & BC094478 & 1.204 & 2 & \\
\hline & SKPSLPPGLSETDASTGK & LOC549028 & NM_00106274 & 1.197 & 2 & \\
\hline & DETWVNVSSPPLLEDPLLK & MGC: 116540 & BC099345 & 1.181 & 2 & \\
\hline
\end{tabular}

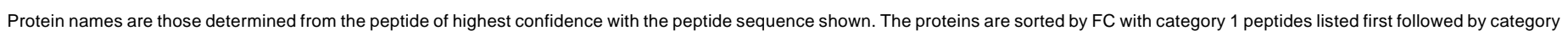

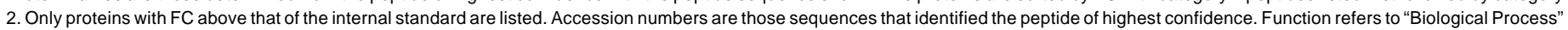

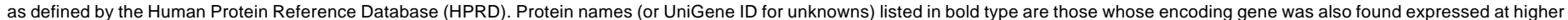

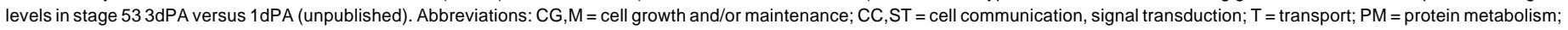

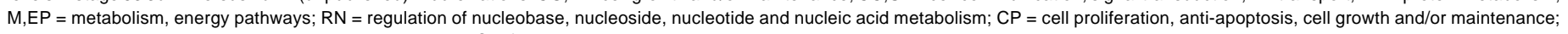
$\mathrm{A}=$ apoptosis; $\mathrm{IR}=$ immune response; $\mathrm{UNK}=$ unknown; $\mathrm{FC}=$ fold change.

free proteomics. However, as our cut-off for determining whether or not to include multiple examples of the same peptide in Tables 2 and 3 , we used the more conservative value of $20 \%$ reproducibility in the FC differences between two or more instances of the same peptide.

A relatively large disagreement in fold changes for the same peptide in replicate measurements might be due to a number of subtle phenomena. For example, variable post-translational modifications such as oxidation, signal levels near the mass spectrometer's limit of detection, and the presence of co-eluting peptides with strong signals whose intensity or retention time changes, could all contribute to inconsistent fold changes across replicates. Taking into account the fact that different peptides representing the same protein (but with different FC values) were identified, Table 2 contains 122 unique annotated proteins along with the 9 unknowns, and Table 3 contains 192 unique annotated proteins and 10 unknowns.

In our previous array screens [(Grow et al., 2006) and unpublished 3dPA data] we identified a much larger number of differentially expressed genes between two pairs of limb tissues. However, we believe that the total number of protein differences we found in the present study is highly relevant for several reasons.
Our complex proteomic analysis was carried out using tryptic digests from whole limb stump or blastema tissue. There was no fractionation of the samples prior to injection of the tryptic peptides into the LC column, yet we were able to identify 1517 differentially expressed proteins. Since subcellular fractionation prior to proteomic analysis can greatly enhance the identification of low abundance proteins (Mitulovic and Mechtler, 2006; Brown et al., 2007), detection of such proteins is likely to be limiting in our assay. Indeed many proteins one might have expected to show significant FCs based on our previous array screens were not identified. In addition, we have analyzed the differences in gene expression between 1dPA and 3dPA in stage 53 limbs (unpublished), and among those with higher expression at 3dPA are 30 genes encoding proteins listed in Table 2 (e.g. ANXA1, ITGVAV, IRF2BP2, SMARCA4, and PSAP). Lastly, as discussed below several proteins identified in our study have been shown to be differentially expressed in other models of limb regeneration.

The proteins found more highly concentrated in limb tissues following amputation were functionally classified by their biological process using categories defined by the Human Protein Reference Database [www.hprd.org; ref. (Peri et al., 2003)]. As indicated in Table 2 most of the proteins are involved in cell growth 
A

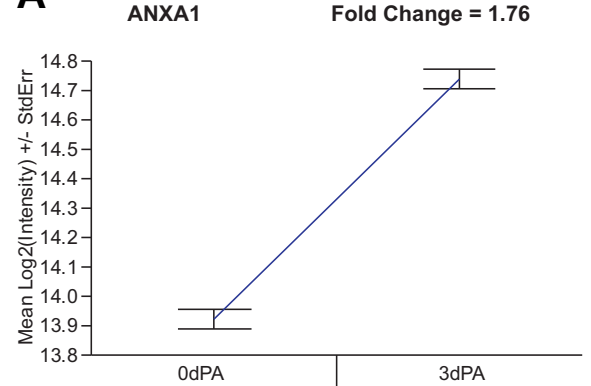

B

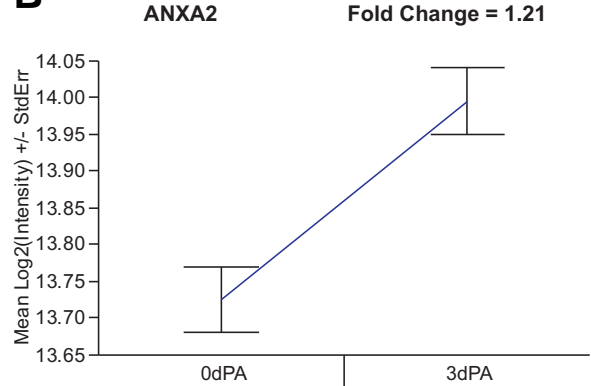

C

S100A10

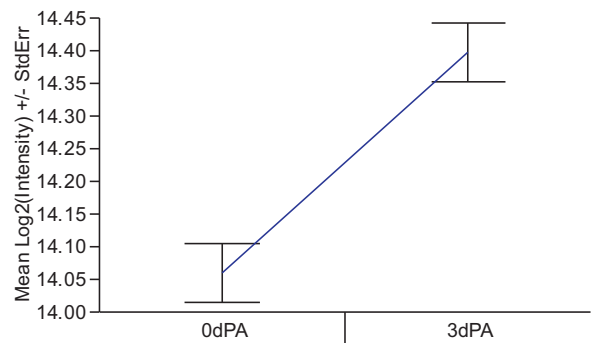

Fig. 1. Peptide fold-changes. Mean log2 intensity comparisons for ANXA1, ANXA2 and the ANXA2-binding partner S100A10. Relative protein expression levels at OdPA compared to 3dPA represent the mean value determined from 10 independent injections. The intensities which are given by the area under the curve (AUC) from the extracted ion chromatography (XIC) were transformed to the log 2 scale. Error bars show standard errors based on the ANOVA model.

and maintenance, cell communication or signal transduction, transport, metabolism and energy pathways. The cell growth and maintenance proteins include specific keratins that were identified in previous immunocytochemical studies as up-regulated in adult newt limb regeneration (see Discussion). Many other abundant proteins listed in Table 2, including matrix metalloproteinases, fibronectin, type I collagen, vimentin, and non-muscle myosin have also been found to be expressed or concentrated more highly in regenerating adult urodele limbs using unrelated methods (reviewed by Geraudie and Ferretti, 1998). Our identification here of many specific proteins shown by other investigators to appear after limb amputation in other species and using completely different experimental techniques, strongly supports the validity of the proteomics approach to the understanding of the regulation of regeneration in this system.

Since stage 53 limbs consist almost entirely of proliferating epithelial and mesenchymal cells it is not surprising that a significant percentage of the proteins we identified at elevated levels in such limbs (0dPA) are members of the DNA replication process, RNA synthesis and translation (Table 3). Ribosomal proteins and translation factors represent $24 \%$ of the proteins identified by high confidence peptides. Protein families that are involved in replication, RNA synthesis and transport including replication licensing factors, histones, ribonucleoproteins and chaperones constituted the next highest percentage of identified peptides.

Amputation of stage 53 limbs interrupts the rapid cell proliferation to allow for epithelial closure of the wound and the inflammatory response which together initiate wound repair and then, by $3 \mathrm{dPA}$, the events which lead to limb regeneration. Therefore, a reduced number of growth and proliferation associated proteins in the 3dPA tissue is to be expected and was in fact found. While, the peptides identified in our screen represent statistically significant differences between the two time points, it is still important to note that we did not find any peptides in 3dPA tissue that were also in OdPA tissue (compare Tables 2 and 3 ).

\section{Proteins with immune function}

Microarray and other gene expression studies suggest that proteins involved in immune defense and other aspects of inflammation are particularly important in the post-amputation regenerative response of amphibian limbs (Harty et al., 2003; Grow et al., 2006; Mescher and Neff, 2006). Similar results are reported in other regenerating systems (Putta et al., 2004; Lien et al., 2006;
Schebesta et al., 2006), although the inflammatory process as a whole represents a poorly studied aspect in any model of epimorphic regeneration. To identify additional factors with immune-related activity among the proteins up-regulated three days after amputation, we compared our data with the results of gene expression analyses of various immune cell types, e.g. that of Abbas et al., (2005) and other reports of immune function. Among the 136 up-regulated proteins, 24 were identified as having immune-related functions (Table 4). These include components of the coagulation pathway and of the complement cascade (C1QBP); proteins with antimicrobial activity (e.g. lactoferrin); markers for macrophages, neutrophils, and other leukocytes (e.g. granulin, vimentin, myeloperoxidase); as well as factors with both pro- and anti-inflammatory activity (e.g. interferon regulatory factor 2 binding protein).

Of the immune-related proteins differentially expressed in this screen we chose members of the annexin family for further analysis. Expression of annexins has been demonstrated in most molecular screens of regeneration markers in several model systems; and as discussed below, well-characterized functions of annexins have potential importance to the regeneration process. It is of interest that of 13 annexin family members four (ANXA1, ANXA2, ANXA5, and ANXA7) were significantly higher in the 3dPA blastemas compared to the 0dPA limbs. Each of these four annexins was detected at a fold change higher than the chicken lysozyme internal standard. By contrast only one annexin (ANXA6) was higher in 0dPA limbs (see Table 3).

ANXA1 and ANXA2 were each identified with multiple sequences and ANXA1 was among those proteins most strongly upregulated 3 days after amputation. Shown in Figure 1 are the relative protein expression levels, identified at OdPA and 3dPA, for ANXA1 and ANXA2 and S100A10 (an important dimerization partner with ANXA2). These represent the mean expression level determined from the 10 independent injections (see Methods). Protein levels are presented as the log base 2 value after quantile normalization, and the fold change for these and all proteins in Tables 2 and 3 is determined from the antilog values of expression level.

In order to compare protein differences to gene expression level differences we assessed the relative expression levels before and after amputation of $A N X A 1, A N X A 2$, and $S 100 A 10$ by quantitative RT-PCR (Figure 2). These results indicate that gene expression of all three is up-regulated 3 days after amputation. As 
TABLE 3

\section{PROTEINS EXPRESSED AT ELEVATED LEVELS IN OdPA RELATIVE TO 3dPA}

\begin{tabular}{|c|c|c|c|c|c|c|}
\hline Protein Identification by Peptide(s) & Peptide & UniGene & Accession & FC & Category & Biological Process \\
\hline histone H2A & AGLQFPVGR & H2A.Z12 & BC044011 & 2.256 & 1 & $\mathrm{RN}$ \\
\hline ribonucleotide reductase subunit M1 & DLFYAMWIPDLFMK & RRM1 & BC074185 & 1.395 & 1 & $\mathrm{RN}$ \\
\hline histone H2A & AGLQFPVGR & H2A.Z12 & BC044011 & 1.377 & 1 & $\mathrm{RN}$ \\
\hline proliferating cell nuclear antigen & AEDNADTVTMVFESPNQEK & PCNA & BC080365 & 1.328 & 1 & DNAR \\
\hline similar to histone $\mathrm{H} 1.4$ (histone $\mathrm{H} 1 \mathrm{~b}$ ) & SGVSLAALK & H1E & X03017 & 1.293 & 1 & $\mathrm{RN}$ \\
\hline oocyte translation elongation factor 1 alpha & IGGIGTVPVGR & EEF1A & BC045083 & 1.282 & 1 & PM \\
\hline DNA replication licensing factor 7 & YTNLFADAVQELLPQYK & MCM7 & BC067307 & 1.281 & 1 & RN \\
\hline fascin & ISCFSPSVSPAEK & FSCN1 & BC097600 & 1.263 & 1 & $\mathrm{CP}$ \\
\hline ribosomal protein S15 & GVDLDQLLDMSYEQVMQLYCAR & RPS15 & BC053812 & 1.258 & 1 & RN \\
\hline $\mathrm{H} 2 \mathrm{~A}$ histone family, member $\mathrm{V}$ & GDEELDSLIK & H2AFV & BC091605 & 1.251 & 1 & RN \\
\hline fusion protein in $\mathrm{t}(12 ; 16)$ of malignant liposarcoma & AAIDWFDGK & FUS & NM_001092824 & 1.248 & 1 & $\mathrm{RL}$ \\
\hline $\begin{array}{l}\text { cytosolic thyroid hormone binding protein/pyruvate kinase type } \\
\text { M2 }\end{array}$ & GDLGIEIPAEK & PKM2 & BC079921 & 1.243 & 1 & $\mathrm{M}, \mathrm{EP}$ \\
\hline DNA replication licensing factor 2 & AAEGAPEEDEEMIESIENLEDMK & MCM2 & BC046274 & 1.236 & 1 & RN \\
\hline glutamate oxaloacetate transaminase 2 & NLDKEYLPIGGLAEFAR & GOT2/ASP2 & BC045269 & 1.233 & 1 & $\mathrm{M}, \mathrm{EP}$ \\
\hline RAB11B, member RAS oncogene family & VVLIGDSGVGK & RAB11B & BC041250 & 1.232 & 1 & $\mathrm{CC}, \mathrm{ST}$ \\
\hline macrophage migration inhibitory factor & DSVPDTLLSDLTK & MIF & BC097727 & 1.232 & 1 & $\mathrm{CC}, \mathrm{ST}$ \\
\hline heterogeneous nuclear ribonucleoprotein $\mathrm{K}$ & VILDLISESPVK & HNRPK & BC044711 & 1.223 & 1 & $\mathrm{RN}$ \\
\hline $\begin{array}{l}\text { SWI/SNF related, matrix associated, actin dependent } \\
\text { regulator of chromatin, subfamily c, member } 1\end{array}$ & ALAALVSQLLQFQEDAFGR & SMARCC1 & BC044014 & 1.223 & 1 & $\mathrm{RN}$ \\
\hline chaperonin containing TCP1 subunit 5 & CPSLEQYAMR & СCT5 & BC044997 & 1.222 & 1 & PM \\
\hline glycine cleavage system protein $\mathrm{H}$ & MTVDNPSELDDLMSEDAYEK & GCSH & AL845787 & 1.221 & 1 & $\mathrm{M}, \mathrm{EP}$ \\
\hline high density lipoprotein binding protein (vigilin) & VVTEIMQETGTR & HDLBP & BC044314 & 1.216 & 1 & $\mathrm{~T}$ \\
\hline RAN, $25 \mathrm{kDa}$ ras-related protein & VCENIPIVLCGNK & RAN & BC074619 & 1.216 & 1 & $\mathrm{CC}, \mathrm{ST}$ \\
\hline heterogeneous nuclear ribonucleoprotein $\mathrm{K}$ & GSFGDIGGPVVTTQVTIPK & HNRPK & BC044711 & 1.215 & 1 & $\mathrm{RN}$ \\
\hline small nuclear ribonucleoprotein polypeptide D2 isoform & REEEEFNTGPLSVLTQSVK & SNRPD2 & CX467787 & 1.212 & 1 & RN \\
\hline heteronuclear ribonucleoprotein $A / B$ & IFVGGLNPEAGEDK & HNRPAB & NM_001087020 & 1.212 & 1 & $\mathrm{RN}$ \\
\hline chaperonin containing TCP1 subunit 4 & VIDPQTANSVDLR & CCT4 & BC076940 & 1.211 & 1 & PM \\
\hline heteronuclear ribonucleoprotein A/B & GEEDAGCVADISSPLTEGVK & HNRPAB & NM_001087020 & 1.208 & 1 & $\mathrm{RN}$ \\
\hline histone 2, H2bf & AMSIMNSFVNDVFER & $\mathrm{H} 2 \mathrm{BF}$ & CR855675 & 1.208 & 1 & RN \\
\hline lamina-associated protein-2 beta isoform & EMFPTEFSTPTGISASCR & LOC780742 & AF048815 & 1.207 & 1 & UNK \\
\hline zinc finger protein 326 & SQGGSSWDPSFTR & ZNF326 & CR762202 & 1.207 & 1 & $\mathrm{RN}$ \\
\hline DNA replication licensing factor 3 & TPMENIGLQDSLLSR & MCM3 & BC089251 & 1.205 & 1 & RN \\
\hline translation initiation factor- 5 & EDLKIPDGDLGK & EIF5 & BC045007 & 1.202 & 1 & PM \\
\hline ribosomal protein L5 & RFPGYDSESK & RPL5 & BC059751 & 1.200 & 1 & PM \\
\hline SET translocation & VEVTEFEDIK & SET & CK740651 & 1.199 & 1 & $\mathrm{RN}$ \\
\hline chaperonin containing TCP1 subunit 5 & AFADALEIIPMSLAENSGMNPIQTMTEVR & CCT5 & BC044997 & 1.197 & 1 & PM \\
\hline HMG-X protein & LGELWAEQTPK & MGC52578 & BC044715 & 1.197 & 1 & UNK \\
\hline similar to ADP-ribosylation factor-like 6 interacting protein & WQNNLLPSR & ARL6IP & BG579961 & 1.197 & 1 & RN \\
\hline moderately similar to RNA-binding protein AUF1 & IFVGGLSPDTPEDK & HNRPD & BC097855 & 1.196 & 1 & $\mathrm{RN}$ \\
\hline histone $\mathrm{H} 3 \mathrm{a}$ & ALQEASEAYLVGXFEDTNLCAIHAK & $\mathrm{H} 3 \mathrm{~A}$ & DQ284418 & 1.196 & 1 & RN \\
\hline zygotic DNA replication licensing factor 6-B & CDFTGSLIVVPDISQLSTPGVR & MCM6b & AF031139 & 1.193 & 1 & $\mathrm{RN}$ \\
\hline heterogeneous nuclear ribonucleoprotein $\mathrm{R}$ & DLFEDELVPLFEK & HNRPR & CA988055 & 1.192 & 1 & RN \\
\hline $\begin{array}{l}\text { similar to SWI/SNF-related matrix-associated actin-dependent } \\
\text { regulator of chromatin c2 }\end{array}$ & LNPQEYLTSTACR & SMARCC2 & $\mathrm{BC} 136222$ & 1.191 & 1 & RN \\
\hline high mobility group protein $2 \mathrm{a}$ & LGEMWNNLSDGEK & HMG2a & BC123147 & 1.191 & 1 & $\mathrm{RN}$ \\
\hline glycerol-3-phosphate dehydrogenase 1-like & LPENVVALPNLTDAVR & GPD1L & BC076683 & 1.189 & 1 & UNK \\
\hline TAR DNA-binding protein & TSDLIVLGLPWK & TARDBP & BC044271 & 1.188 & 1 & RN \\
\hline ribosomal protein L31 & LYTLVTYVPVTNYK & RPL31 & BC077057 & 1.186 & 1 & PM \\
\hline proteosome subunit beta type 1 & AGGSASAMLQPLLDNQIGYK & PSMB1 & NM_001086966 & 1.184 & 1 & PM \\
\hline weakly similar to $60 \mathrm{~S}$ acidic ribosomal protein P2 & LSSVPCGGAVSAAPASTPAAGGAAPAEK & RPLP2 & BC023136 & 1.184 & 1 & PM \\
\hline nucleosome assembly protein 1-like 1 & QLTAQMMQNPQVLAALQER & NAP1L1 & NM_001087078 & 1.182 & 1 & $\mathrm{RN}$ \\
\hline moderately similar to $60 \mathrm{~S}$ acidic ribosomal protein $\mathrm{P} 1$ & TAGVTVEPFWPSLFAK & RPLP1 & BC097516 & 1.176 & 1 & PM \\
\hline ribosomal protein S4 & TDITYPAGFMDVISIEK & RPS4 & BC106700 & 1.175 & 1 & PM \\
\hline adenosine kinase a & AGCTLPEKPDFI & ADKA & BC075155 & 1.175 & 1 & RN \\
\hline nuclear phosphoprotein & DNDSCPTSLLDIFSDWVK & xNopp180 & NM_001088086 & 1.174 & 1 & UNK \\
\hline protein phosphatase 2 regulatory subunit $A$ & NDLIPLFTNLASDEQDSVR & PPP2R1A & BC078080 & 1.174 & 1 & $\mathrm{CC}, \mathrm{ST}$ \\
\hline ribosomal protein S16 & LLEPVLLLGK & RPS16 & NM_001016347 & 1.173 & 1 & PM \\
\hline similar to ribophorin II & LLVTNVLSQPLTEAK & RPN2 & BC046727 & 1.173 & 1 & PM \\
\hline similar to histone $\mathrm{H} 2 \mathrm{~b}$ & NSFVNDIFER & $\mathrm{H} 2 \mathrm{~B}$ & BC077399 & 1.172 & 1 & $\mathrm{RN}$ \\
\hline
\end{tabular}


TABLE 3 (continued)

PROTEINS EXPRESSED AT ELEVATED LEVELS IN OdPA RELATIVE TO 3dPA

\begin{tabular}{|c|c|c|c|c|c|c|}
\hline Protein Identification by Peptide(s) & Peptide & UniGene & Accession & FC & Category & Biological Process \\
\hline ribosomal protein L10 & VDEFPLCGHMVSDEYEQLSSEALEAAR & RPL10 & BC044716 & 1.169 & 1 & PM \\
\hline heteronuclear ribonucleoprotein $\mathrm{H} 2$ & ATETDIYTFFSPLNPVR & HNRPH2 & BC074690 & 1.168 & 1 & RN \\
\hline similar to myelin expression factor 2 & NLPFDLTWQK & MYEF2 & NM_001016035 & 1.166 & 1 & RN \\
\hline ribosomal protein S8 & LDAGNFSWGSECCTR & RPS8 & BC054266 & 1.162 & 1 & PM \\
\hline splicing factor U2AF large chain & LFIGGLPNYLNDDQVK & U2AF2 & BC044032 & 1.162 & 1 & RN \\
\hline DNA replication licensing factor 5 & LQPFATETDVEEALR & MCM5 & BC059310 & 1.162 & 1 & $\mathrm{RN}$ \\
\hline ribosomal protein SA & AIVAIENPADVCVISSR & RPSA & BC061298 & 1.161 & 1 & $\mathrm{CC}, \mathrm{ST}$ \\
\hline glutathione-S-transferase, mu1 & FEALPAIDAYMK & GSTM1 & BC053774 & 1.161 & 1 & $\mathrm{M}, \mathrm{EP}$ \\
\hline histone $\mathrm{H} 3 \mathrm{a}$ & GLFEDTNLCAIHAK & $\mathrm{H} 3 \mathrm{~A}$ & NM_001097650 & 1.161 & 1 & $\mathrm{RN}$ \\
\hline glutathione-S-transferase, mu 2 & LGLDFPNLPYLVDGDVK & GSTM2 & BC053774 & 1.160 & 1 & M,EP \\
\hline \multicolumn{2}{|c|}{ acidic (leucine-rich) nuclear phosphoprotein 32 family, member E CPNITYLNLSGNK } & ANP32E & BC094475 & 1.158 & 1 & UNK \\
\hline nucleolin & VLVVNNLSYSATEDSLR & $\mathrm{NCL}$ & X72957 & 1.158 & 1 & RN \\
\hline dynein light chain, LC8-type 2 & NADMSEEMQQDAVECATQALEK & DYNLL2 & BC068877 & 1.158 & 1 & CG,M \\
\hline U2 small nuclear ribonucleoprotein auxiliary factor 2 & LGGLTQAPGNPVLAVQINQDK & U2AF2 & BC067966 & 1.155 & 1 & $\mathrm{RN}$ \\
\hline chaperonin-containing TCP1 subunit 2 & VQDDEVGDGTTSVTVLAAELLR & ССТ2 & NM_001086919 & 1.151 & 1 & PM \\
\hline translation elongation factor-1 gamma & WFVTCVNQPEFR & EEF1G & NM_001088012 & 1.144 & 1 & PM \\
\hline poly $(\mathrm{rC})$ binding protein 2 , hnRNP-E2 protein & IITLAGPTNAIFK & PCBP2 & BC084195 & 1.144 & 1 & RN \\
\hline ribosomal protein L5 & NGVTADQVEDLYK & RPL5 & BC041227 & 1.143 & 1 & PM \\
\hline DEAD-box polypeptide 5 & MLDMGFEPQIR & DDX5 & BC063223 & 1.143 & 1 & RN \\
\hline ribosomal protein L4 & IEEIPEVPLVVEDK & RPL4 & BC106315 & 1.142 & 1 & PM \\
\hline similar to ribosomal protein L24 & AITGASLAEIMAK & RPL24 & Y17113 & 1.140 & 1 & PM \\
\hline similar to heterogeneous nuclear ribonucleoprotein D-like & QYFGGFGEIENIELPIDTK & HNRPD & BC045124 & 1.140 & 1 & RN \\
\hline similar to heterogeneous nuclear ribonucleoprotein G & LFIGGLNTETNEK & HNRPG & BC070649 & 1.139 & 1 & RN \\
\hline chaperonin-containing TCP1 subunit 8 & FAEAFESIPR & ССТ8 & NM_001087244 & 1.137 & 1 & PM \\
\hline ribosomal protein S12 & LGEWVGLCK & RPS12 & NM_001087125 & 1.137 & 1 & PM \\
\hline annexin A6 & VILGLMMTPAQFDAK & ANXA6 & BC073422 & 1.136 & 1 & $\mathrm{CC}, \mathrm{ST}$ \\
\hline ribosomal protein L23a & LAPDYDALDVANK & RPL23A & BC087796 & 1.135 & 1 & PM \\
\hline malate dehydrogenase 1 , NAD (soluble) & IVEGLCINDFSR & MDH1 & BC075396 & 1.133 & 1 & $\mathrm{M}, \mathrm{EP}$ \\
\hline ribosomal protein L11 & VLEQLTGQTPVFSK & RPL11 & BC135522 & 1.133 & 1 & PM \\
\hline $\mathrm{H} 2 \mathrm{~A}$ histone family, member Y2 & EVASSSTSDDGPGDAFTILSSK & $\mathrm{H} 2 \mathrm{AFY} 2$ & BC056065 & 1.133 & 1 & RN \\
\hline \multicolumn{2}{|c|}{ heterogeneous nuclear ribonucleoprotein $U$ scaffold attachement } & HNRPU & NM_001097364 & 1.131 & 1 & RN \\
\hline similar to prohibitin 2 isoform 1 & VPWFQYPIIYDIR & PHB2 & NM_001092833 & 1.125 & 1 & $\mathrm{RN}$ \\
\hline keratin 16 & IGSLEEQLQQIR & KRT16 & NM_001086376 & 1.123 & 1 & CG,M \\
\hline retinoblastoma-A associated protein, RbAp48 & YMPQNPCIIATK & RBBP4 & AF073787 & 1.121 & 1 & RN \\
\hline 54kDa nuclear RNA-binding protein & FGQAPNIEGLGGANPPAFPR & P54NRB & BC045128 & 1.119 & 1 & RN \\
\hline translation elongation factor- 1 alpha & SGDAAIVDMIPGKPMCVESFSDYPPLG & EEF1A & $\mathrm{BC} 043843$ & 1.119 & 1 & PM \\
\hline histone $\mathrm{H} 2 \mathrm{~A}$ & EGASSSTSDDGPGDAFTILSSK & $\mathrm{H} 2 \mathrm{~A}$ & BC076893 & 1.118 & 1 & RN \\
\hline ubiquitin-activating enzyme E1 & VYDDDFFEALDGVANALDNIDAR & UBE1 & AB040073 & 1.118 & 1 & PM \\
\hline cleavage and polyadenylation specific factor $6,68 \mathrm{kDa}$ & AVSDASAGDYGSAIETLVTAISLIK & CPSF6 & BC077388 & 1.116 & 1 & RN \\
\hline DNA replication licensing factor 4 & SLNPEDIDQLITISGMVIR & MCM4 & BC074670 & 1.116 & 1 & RN \\
\hline heterogeneous nuclear ribonucleoprotein D-like & VFVGGLSPETTEEQIK & HNRPD & BC045124 & 1.115 & 1 & $\mathrm{RN}$ \\
\hline thioredoxin domain containing 5 & DLETLQNYVLR & TXNDC5 & BC045245 & 1.115 & 1 & PM \\
\hline RNA and export factor binding protein 2 & MDMSLDDIIK & REFBP2 & BC135842 & 1.114 & 1 & UNK \\
\hline arginine methyltransferase- $1 \mathrm{~b}$ & DVAIKEPLVDVVDPK & PRMT1 & BC072069 & 1.114 & 1 & $\mathrm{M}, \mathrm{EP}$ \\
\hline RNA-binding protein Vera & ITISPLQDLTLYNPER & VERA-A & AF055923 & 1.110 & 1 & UNK \\
\hline chaperonin containing TCP1 subunit 6 A (zeta 1) & VLAQNSGYDPQETLVK & ССТ6 & BC084219 & 1.110 & 1 & PM \\
\hline chaperonin-containing TCP1 subunit 7 & LPIGDVATQYFADR & CCT7 & NM_001093568 & 1.109 & 1 & PM \\
\hline translation initiation factor-3 subunit 10 & DIDIENLEELDPDFIMAK & EIF3S10 & BC043785 & 1.108 & 1 & PM \\
\hline retinoblastoma binding protein $7, \mathrm{RbBP7}$ & TPSADVLVFDYTK & RBBP7 & BC064219 & 1.108 & 1 & $\mathrm{RN}$ \\
\hline telomerase binding protein, p23 & YLNEVELFQSIDPNASK & TEBP & BC084900 & 1.104 & 1 & UNK \\
\hline ras-GTPase-activating protein SH3-domain-binding protein & LPNFGFVVFDDAEPVQK & G3BP & BC045051 & 1.102 & 1 & $\mathrm{CC}, \mathrm{ST}$ \\
\hline DNA unwinding factor 87, DUF87 & SENPGISITDLSK & SSRP1 & BC082613 & 1.101 & 1 & RN \\
\hline ribosomal protein L23 & LPVGAVINCADNTGGK & RPL23 & BC073541 & 1.100 & 1 & PM \\
\hline pre-mRNA processing factor- 8 & LANQLLTDLVDDNYFYLFDLK & PRP8 & NM_001086784 & 1.100 & 1 & RN \\
\hline $20 S$ proteasome alpha1 subunit & YGYEIPVDMLCK & LOC446974 & BC084423 & 1.096 & 1 & UNK \\
\hline translation elongation factor-2 & IWCFGPDGSGPNILTDVTK & EEF2 & NM_001087187 & 1.095 & 1 & PM \\
\hline pre-mRNA processing factor- 19 homolog & SASVPGILALDLCPTDTNK & PRPF19 & BQ732328 & 1.094 & 1 & RN \\
\hline septin A & STLINSLFLTDLYPER & SEPTA & AF212298 & 1.094 & 1 & UNK \\
\hline
\end{tabular}


TABLE 3 (continued)

PROTEINS EXPRESSED AT ELEVATED LEVELS IN OdPA RELATIVE TO 3dPA

\begin{tabular}{|c|c|c|c|c|c|c|}
\hline Protein Identification by Peptide(s) & Peptide & UniGene & Accession & FC & Category & Biological Process \\
\hline ribosomal protein $\mathbf{S 1}$ & DEIVPTTPISEQK & RPS1 & BC130166 & 1.092 & 1 & UNK \\
\hline pleckstrin homology domain containing, family $\mathrm{C}$ member 1 & TSTILGDITSIPELTDYLK & PLEKHC1 & BC077819 & 1.223 & 2 & UNK \\
\hline $26 \mathrm{~S}$ proteosome non-ATPase regulatory subunit 14 & LGGGMPGLGQGPPTDAPAVDTAEQVYISSLALLK & PSMD14 & BC045094 & 1.223 & 2 & PM \\
\hline valyl-tRNA synthetase like & LLSPFMPFLTEELYQR & VARS2L?VARSL & BC084762 & 1.222 & 2 & $\mathrm{M}, \mathrm{EP}$ \\
\hline DNA replication licensing factor 4 & SLNPEDIDQLITISGMVIR & MCM4 & BC074670 & 1.222 & 2 & $\mathrm{RN}$ \\
\hline dynein light chain, DLC8a & DIAAFIK & DYNLL2 & BC088794 & 1.214 & 2 & $\mathrm{CG}, \mathrm{M}$ \\
\hline FHA domain-interacting nucleolar phosphoprotein-like & SLIEPQLQEYFNQFGTVTR & MKI67IPL & BC122487 & 1.201 & 2 & UNK \\
\hline SET translocation & VEVTEFEDIK & SET & CK740651 & 1.197 & 2 & RN \\
\hline keratin 18 & LEMLGGTAMALETELVQ & KRT18 & Y00230 & 1.197 & 2 & $\mathrm{CG}, \mathrm{M}$ \\
\hline transcription factor IID subunit & SIAGLAELGPDVV & TAF6 & BC068776 & 1.190 & 2 & RN \\
\hline spermatid perinuclear RNA binding protein & GWPLELICEK & STRBP & $\mathrm{BC} 078118$ & 1.185 & 2 & $\mathrm{RN}$ \\
\hline ubiquitin-conjugating enzyme E2 variant 1 & NPDGTMNLMNWECAIPGK & UBE2V1 & BC045066 & 1.184 & 2 & $\mathrm{CD}$ \\
\hline nuclear receptor coactivator 5 & GVAPPGIQAVLGLLADNR & NCOA5 & BC044688 & 1.181 & 2 & RN \\
\hline poly $(\mathrm{rC})$ binding protein 3 & LVVPASQCGSLIGK & РСВР3 & CR855568 & 1.180 & 2 & RN \\
\hline Williams-Beuren syndrome chromosome region 1 & ELPTEPPFTAYVGNLPFNTVQGDIDNIFK & WBSCR1 & BC078074 & 1.179 & 2 & UNK \\
\hline similar to heterogeneous ribonuclear particle protein & SYGGDGFGNDGGFGGSPPYSGGNR & HNRPA1 & BC045260 & 1.178 & 2 & $\mathrm{RN}$ \\
\hline replication protein $\mathrm{A} 3$ & NATVELNEPLEEEISGIIEVIGK & RPA3 & BC077497 & 1.178 & 2 & RN \\
\hline golgi phosphoprotein 3 & ETPTPETVQSWIELLSGETWNPLK & GOLPH3 & CR760594 & 1.176 & 2 & $\mathrm{~T}$ \\
\hline creatine kinase, brain & GGDDLDPNYVLSSR & CKB & BC042282 & 1.176 & 2 & $\mathrm{M}, \mathrm{EP}$ \\
\hline $\begin{array}{l}\text { similar to 3-hydroxy-3-methylglutaryl-coenzyme A reductase, } \\
\text { HMGCoA reductase }\end{array}$ & FLLLIDLSR & HMGCR & BC074197 & 1.174 & 2 & $\mathrm{M}, \mathrm{EP}$ \\
\hline DNA unwinding factor $140 \mathrm{kDa}$ subunit & TLMVDPTQEMQENYNFLLQLQEELLK & SUPT16H & NM_001090697 & 1.168 & 2 & $\mathrm{RN}$ \\
\hline RAN-binding protein 7 & MDPNILIEALRGTM & IPO7 & BC046568 & 1.166 & 2 & $\mathrm{~T}$ \\
\hline similar to PR domain containing 2, with ZNF domain & NIPQTFTTAIR & PRDM2 & BC100183 & 1.166 & 2 & RN \\
\hline methylenetetrahydrofolate dehydrogenase (NADP+ dependent) 1 & 1 FLYDVQLPIADK & MTHFD1 & BC080885 & 1.166 & 2 & $\mathrm{M}, \mathrm{EP}$ \\
\hline 5'-3'-exoribonuclease-2 & FAWQGVALLPFVDER & XRN2 & CR848514 & 1.166 & 2 & RN \\
\hline wnt inhibitory factor-1 & VNVIVMNSEGNVILQ & WIF1 & AF122924 & 1.163 & 2 & $\mathrm{CC}, \mathrm{ST}$ \\
\hline $146 \mathrm{kDa}$ nuclear protein & EFGAGPLFNQILPLLMSPTLEDQER & SF3B1 & BC097718 & 1.162 & 2 & RN \\
\hline DNA-dependent RNA polymerase subunit & PSEGVTGDLIINNNV & MGC80013 & BC070564 & 1.162 & 2 & UNK \\
\hline similar to transmembrane protein 6 & LFLIMLVLK & TMED6 & BC084087 & 1.162 & 2 & $\mathrm{~T}$ \\
\hline SAPS domain family, member 2 & LLKNMFDGE & SAPS2 & $\mathrm{BC} 073386$ & 1.162 & 2 & UNK \\
\hline armadillo repeat containing protein 6 & MIVLENGGLK & ARMC6 & BC076906 & 1.161 & 2 & SS,ST \\
\hline histone $\mathrm{H} 1 \mathrm{~A}$ variant & AAAAAGAAK & $\mathrm{H} 1 \mathrm{~A}$ & NM_001095702 & 1.160 & 2 & $\mathrm{RN}$ \\
\hline ubiquitin-activating enzyme E1 & VYDDDFFEALDGVANALDNIDAR & UBE1 & AB040073 & 1.159 & 2 & PM \\
\hline RAN-binding protein 1 & FASENDPPEWK & RANBP1 & BC054182 & 1.159 & 2 & $\mathrm{RN}, \mathrm{ST}$ \\
\hline small nuclear ribonucleoprotein polypeptide D3 & FLILPDMLK & SNRPD3 & BC056127 & 1.158 & 2 & $\mathrm{RN}$ \\
\hline $\begin{array}{l}\text { 5-aminoimidazole-4-carboxyamide ribonucleotide } \\
\text { formyltransferase/IMP cyclohydrolase }\end{array}$ & DVSEITGFPEMLGGR & ATIC & BC106381 & 1.157 & 2 & $\mathrm{M}, \mathrm{EP}$ \\
\hline nuclear cap-binding protein subunit 1-B & STSSLESNLEGLAGVLEADLPNYK & NCBP1B & BC072867 & 1.155 & 2 & UNK \\
\hline glypican-4 & LEGPFNIETVMDPIDVK & GPC4 & BC090231 & 1.154 & 2 & $\mathrm{CC}, \mathrm{ST}$ \\
\hline 4-hydroxyphenylpyruvate dioxygenase & LDYNGIFLPGYEPPLFQDPLLPK & HPD & BC084120 & 1.147 & 2 & $\mathrm{M}, \mathrm{EP}$ \\
\hline similar to ribosomal protein $\mathrm{S} 25$ & LNNLVLFDK & RPS25 & NM_001005084 & 1.146 & 2 & PM \\
\hline structure specific recognition proptein 1 & FGGQLLSFDIGDQPAFELPLSNVSQCTTGK & SSRP1 & BC098960 & 1.144 & 2 & RN \\
\hline ribosomal protein L26 & FSPFVTSDR & RPL26 & NM_001005104 & 1.142 & 2 & PM \\
\hline tripeptidyl peptidase II & EMLNYSVNIYDEGNLLSVVTSGGAHG & TPP2 & BC071158 & 1.137 & 2 & PM \\
\hline mitotic phosphoprotein 22 & TNENLEDVEASK & MP22A & AF419149 & 1.134 & 2 & UNK \\
\hline ribonuclease $\mathrm{H} 2$ large subunit & SSTPSVLSFFSAPK & RNASEH2A & BC061614 & 1.134 & 2 & RN \\
\hline nucleophosmin/nucleoplasmin, 3 & LSCQPMVNMGSFEIEAPVTFR & NPM3 & BC043908 & 1.131 & 2 & PM \\
\hline translation initiation factor- 2 subunit 3 & IVLTNPVCTEVGEK & EIF2S3 & BC043966 & 1.128 & 2 & PM \\
\hline ribosomal protein S28 & EGDVLTLLESER & RPS28 & BC080501 & 1.125 & 2 & PM \\
\hline similar to cytochrome $\mathrm{c}$ oxidase subunit IV isoform 2 & AFPLPDIPFQTELSSQQVTLK & COX412 & BC075214 & 1.109 & 2 & $\mathrm{M}, \mathrm{EP}$ \\
\hline translation initiation factor- 3 subunit 10 & LSSLLPFVDAFLLER & EIF3S10 & BC043785 & 1.108 & 2 & PM \\
\hline translation initiation factor-3 subunit 6-interacting protein & GDAQIYEELFNYACPK & EIF3S6IP & NM_001086876 & 1.103 & 2 & PM \\
\hline similar to basic transcription factor 3 -like 4 & QITEMLPGILSQLGADSLTSLR & BTF3L4 & $\mathrm{BC} 087817$ & 1.099 & 2 & UNK \\
\hline U6 snRNA-associated protein & YVQLPADEVDTQLLQDAAR & LSM2 & BC090606 & 1.095 & 2 & RN \\
\hline NADH dehydrogenase (ubiquinone) 1 , alpha/beta subcomplex, 1 & GDLPPLTLENIAER & NDUFA1 & BC106594 & 1.095 & 2 & $\mathrm{M}, \mathrm{EP}$ \\
\hline voltage-dependent anion channel-2 & LTFDTTFSPNTGK & VDAC2 & NM_001016193 & 1.093 & 2 & $\mathrm{~T}$ \\
\hline S-phase kinase associated protein- $1 \mathrm{~A}$ isoform $\mathrm{b}$ & TDDIPVWDQEFLK & SKP1A & BJ092310 & 1.092 & 2 & PM \\
\hline
\end{tabular}


TABLE 3 (continued)

PROTEINS EXPRESSED AT ELEVATED LEVELS IN OdPA RELATIVE TO 3dPA

\begin{tabular}{|c|c|c|c|c|c|}
\hline Protein Identification by Peptide(s) & Peptide & UniGene & Accession & FC & Category Biological Process \\
\hline \multicolumn{6}{|c|}{ Novel, Hypothetical,or Unknown Proteins } \\
\hline & DLSPFGELYEMLK & LOC734164 & BC100168 & 1.366 & 2 \\
\hline & ILPNLPGPK & MGC82736 & BC073514 & 1.337 & 2 \\
\hline & KAPQQQPAASTSAQTKR & LOC733957 & NP_001039134 & 1.244 & 2 \\
\hline & STSEDATSESKR & MGC:85118 & BC091716 & 1.215 & 2 \\
\hline & CLPVNPCPANPR & LOC495265 & BC084326 & 1.205 & 2 \\
\hline & SVAEPENPDHVAEPVTSEGLQQSQTETGK & MGC86492 & BC081276 & 1.199 & 1 \\
\hline & YNDSSSQQLR & MGC83738 & BC070741 & 1.175 & 2 \\
\hline & DLSPFGELYEMLK & IMAGE:4960177 & BC121192 & 1.139 & 1 \\
\hline & LSGLTEVTQLLQEPLNPEQK & MGC:115513 & BC097801 & 1.118 & 2 \\
\hline & DLDDVVNSGLAK & LOC398653 & BC053763 & 1.088 & 2 \\
\hline
\end{tabular}

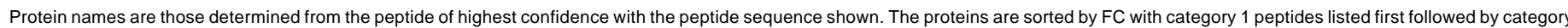

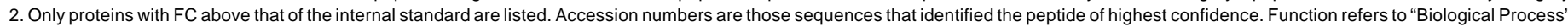

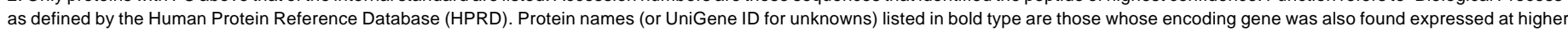

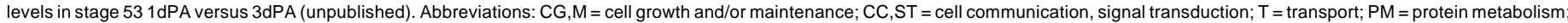

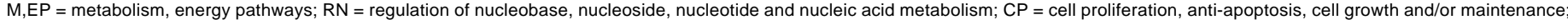
$\mathrm{CD}=$ cell differentiation; $\mathrm{DNAR}=\mathrm{DNA}$ repair $\mathrm{RL}=\mathrm{RNA}$ localization; $\mathrm{UNK}=$ unknown; $\mathrm{FC}=$ fold change .

shown in Table 5 the fold increase from 0dPA to 3dPA is similar for both the mRNA and the protein as determined by LC/MS proteomics and qPCR. All three of these genes were also detected as differentially expressed in our gene array screen (Grow etal., 2006). Microarray analysis (unpublished) showed a 2.8-fold increase in $A N X A 1$, a 2-fold increase in $A N X A 2$, and a 4-fold increase in $S 100 A 10$ in regeneration-competent $3 \mathrm{dPA}$ versus $1 \mathrm{dPA}$ blastemas. Although a comparison of gene expression differences between 1dPA and 3dPA is clearly not identical to the OdPA and 3dPA proteomics comparison, we can infer that many proteins whose levels are increased from 0dPA to 3dPA might also be reflected in an increase in gene expression between $1 \mathrm{dPA}$ and $3 \mathrm{dPA}$.

We showed previously by RT-PCR and qPCR analysis that several 3dPA immune-related genes ( SOCS3, MyD88, gp96, and FGL2) were also greatly up-regulated relative to their levels in intact limbs (Grow et al., 2006). In comparing the pattern of expression of these immune genes in the regeneration-competent limb (stage 53) to that in the non-competent limb (stage 57), we found that the amputation-induced expression was maintained to a much greater extent by $5 \mathrm{dPA}$ at stage 57 . We therefore asked if the expression of $A N X A 1, A N X A 2$ and $S 100 A 10$ showed a similar pattern. The expression of $A N X A 1, A N X A 2$ and $S 100 A 10$ was assessed in stage 53 hindlimbs at $0,1,3$, and 5 days after amputation and compared to expression in similar tissue from hindlimbs at stage 57. All three genes are up-regulated from 3- to 5 -fold within one day of amputation in limbs at both stages (Figure $3)$. In stage 53 limb stumps their expression is maximal 3 days after amputation (5- to 9 -fold) but by 5 days had returned to levels similar to those present at 0 day, possibly reflecting resolution of inflammation as competent blastemas form. In stage 57 hindlimbs undergoing hypomorphic regeneration, the induced expression of these three genes peaks by 1 day after amputation (3- to 5-fold increases), but also returns to near baseline levels by day 5 . Thus, the expression of annexins and S100A10 exhibits a pattern distinct from that of other immune-related genes that we have analyzed following hindlimb amputation.

\section{Proteins expressed in stem cells}

Since cells of the distal amputated limb stump undergo dedifferentiation and proliferate to form the regeneration blastema and the relationship of blastema cells to stem cells is not clear, we also
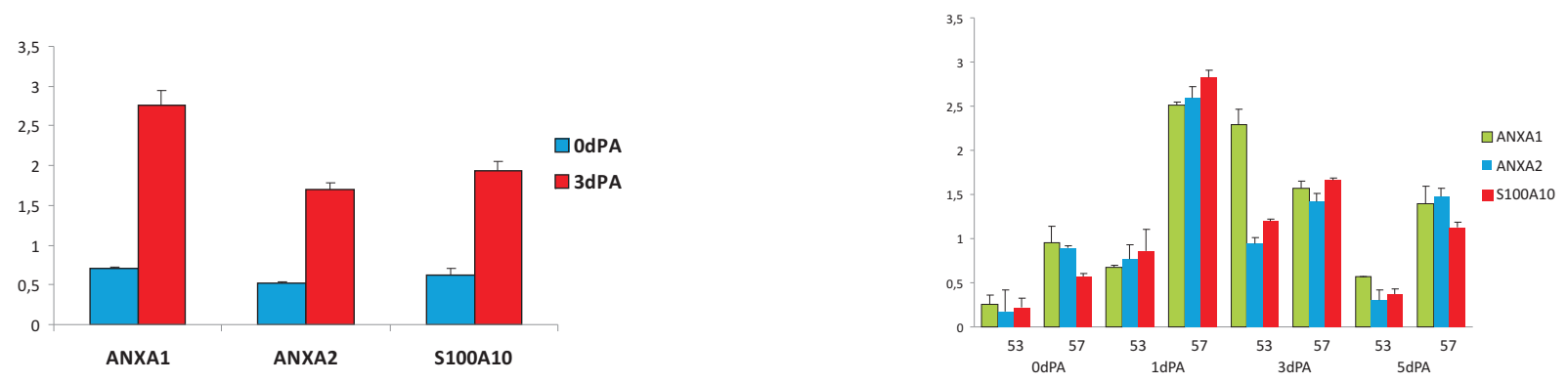

Fig. 2 (Left). qPCR analysis of gene expression. Graphical representation of the qPCR determined level of expression of ANXA1, ANXA2 and S100A 10 in OdPA and 3dPA stage 53 limb tissues normalized to the expression of ODC. Error bars represent the standard deviation from triplicate assays.

Fig. 3 (Right). qPCR analysis of gene expression. Graphical representation of the qPCR determined level of ANXA1, ANXA2 and S100A10 expression, normalized to the expression of ODC, following limb amputation at regeneration-competent and incompetent stages. Expression levels of ANXA1 and ANXA2 and the ANXA2-binding partner S100A10 were assayed by qPCR. OdPA, 1dPA, 3dPA and 5dPA refer to days post-amputation. 53 and 57 refer to Xenopus stages 53 and 57 respectively. Error bars represent the standard deviation from triplicate assays. 
wished to determine whether any of the abundant proteins significantly up-regulated 3dPA have been identified consistently in stem cells. Proteins listed in Table 2 were compared to those identified in mammalian stem cells primarily by proteomic analyses and recently reviewed by Baharvand et al. (2007) and others. As shown in Table 6 nearly thirty of the abundant proteins of various functional classes up-regulated during blastema formation are also expressed in one or more of these stem cells. Eight of these proteins have also previously been shown by gene expression microarray data to undergo increased synthesis after amputation of stage 53 limbs (Grow et al., 2006).

\section{Discussion}

LC/MS proteomic analysis of unfractionated tissue from stage 53 Xenopus hindlimbs at the time of and 3 days after amputation identified and quantified a total of 1517 mostly abundant peptides. Of these, 365 proteins were identified by multiple peptides each with a high level of confidence and found differentially expressed when comparing the two time points. The peptide sequences identified a total of 145 proteins which were found to be higher in 3dPA tissue compared to 0dPA (Table 2). These include proteins involved in many biological processes, with factors related to aspects of innate immunity or inflammation well represented.

One measure of the validity of the proteomic approach we used is the fact that we identified several proteins significantly more concentrated in 3dPA blastemas which have been previously shown to be up-regulated during limb regeneration by other investigators using other species and other analytical methods

TABLE 4

\section{PROTEINS FROM TABLE 2 HAVING ROLES IN IMMUNE FUNCTION AND/OR MODULATION}

\begin{tabular}{|c|c|}
\hline Protein Name & Reference \\
\hline annexin 1 & (Parente and Solito, 2004) \\
\hline annexin 2, annexin II type 1 & (Abbas et al., 2005) \\
\hline annexin 5 & (Munoz et al., 2007) \\
\hline B fibrinopeptide & (Mosesson et al., 2001) \\
\hline calpactin I (annexin II) light chain p11 subunit & (Laumonnier et al., 2006) \\
\hline complement component $1 \mathrm{q}$ subcomponent binding protein & (Abbas et al., 2005) \\
\hline elastase 2 & (Horwitz et al., 2007) \\
\hline fibrinogen alpha & (Ugarova and Yakubenko, 2001) \\
\hline fibrinogen gamma & (Ugarova and Yakubenko, 2001) \\
\hline gelatinase $B$, matrixmetalloproteinase 9 & (Abbas et al., 2005) \\
\hline granulin & (Ong et al., 2006) \\
\hline integrin alpha $V$ subunit & (Schoeler et al., 2003) \\
\hline interferon regulatory factor 2 binding protein 2 & (Childs and Goodbourn, 2003) \\
\hline lymphocyte cytosolic protein 1 & (Abbas et al., 2005) \\
\hline manganese superoxide dismutase & (Abbas et al., 2005) \\
\hline moesin & (Abbas et al., 2005) \\
\hline myeloperoxidase, peroxidase 2 & (Rutgers et al., 2003) \\
\hline phosphatidylserine decarboxylase & (Abbas et al., 2005) \\
\hline prohibitin & (Theiss et al., 2007) \\
\hline putative cathepsin L & (Abbas et al., 2005) \\
\hline slingshot-related protein & (Abbas et al., 2005) \\
\hline transaldolase 1 & (Abbas et al., 2005) \\
\hline transferrin, lactotransferrin & (Weinberg, 2007) \\
\hline vimentin (VIM1, VIM4) & (Benes et al., 2006) \\
\hline
\end{tabular}

Protein names listed in bold type are those whose encoding gene was also found expressed at higher levels in stage $533 \mathrm{dPA}$ versus $1 \mathrm{dPA}$ (unpublished).
(Geraudie and Ferretti, 1998). These include integrin $\alpha \mathrm{V}$ (ITGAV), matrix metalloproteinase 9 (MMP9), collagen type I (COL1A1), fibronectin (FN1), vimentin (VIM) and specific keratins (KRTs). Approximately half of those listed in Table 2 were also identified among genes with significantly up-regulated expression in limb blastemas, as detected by Xenopus laevis microarrays (Grow et al., 2006) or other methods with Ambystoma limbs (Putta et al., 2004) or teleost fins (Katogi et al., 2004).

A previous proteomic comparison of intact and regenerating adult newt limbs analyzed expression of specific proteins by quantitative 2-D gel electrophoresis and autoradiography (Tsonis et al., 1992). One protein up-regulated approximately 10 -fold in the early blastema was identified by partial sequencing as a homolog of Xenopus keratin B2, which we also found induced in this study (Table 2). Database comparison of the partial sequence reported by Tsonis et al. (1992) reveals further homology to newt keratin 17 (KRT17), the keratinocyte-specific antigen recognized

TABLE 5

\section{COMPARISON OF THE FC VALUES FOR ANXA1 AND ANXA2 AND THE ANXA2-BINDING PARTNER, S100A10 DETERMINED BY PROTEOMICS AND QPCR}

\begin{tabular}{cccc} 
& ANXA1 & ANXA2 & S100A10 \\
\hline qPCR & 3.93 & 3.26 & 3.10 \\
Proteomics & 1.76 & 1.21 & 1.26 \\
\hline
\end{tabular}

TABLE 6

\section{PROTEINS FROM TABLE 2 THAT ARE ALSO EXPRESSED AT ELEVATED LEVELS IN VARIOUS MAMMALIAN STEM CELL TYPES}

\begin{tabular}{|c|c|c|}
\hline Protein Name & SC Types & References \\
\hline actin beta & MSC, NSC & (Baharvand et al., 2007) \\
\hline actin gamma & MSC, NSC & (Baharvand et al., 2007) \\
\hline aldolase $\mathrm{A}$ & ESC, MSC & (Baharvand et al., 2007) \\
\hline annexin 1 & MSC, NSC & (Baharvand et al., 2007) \\
\hline annexin 2, annexin II type 1 & MSC, NSC & (Baharvand et al., 2007) \\
\hline annexin 5 & MSC, NSC & (Baharvand et al., 2007) \\
\hline annexin 7 & MSC & (Kim et al., 2006) \\
\hline $\begin{array}{l}\text { ATP-dependent chromatin remodeling } \\
\text { DEXH-box protein }\end{array}$ & NSC & (Matsumoto et al., 2006) \\
\hline ferritin & ADSC & (Zvonic et al., 2007) \\
\hline glutathione-S-transferase & ADSC & (Zvonic et al., 2007) \\
\hline $\begin{array}{l}\text { glyceraldehyde-3-phosphate } \\
\text { dehydrogenase type B }\end{array}$ & MSC, NSC & (Baharvand et al., 2007) \\
\hline keratin & ADSC & (Zvonic et al., 2007) \\
\hline manganese superoxide dismutase & ADSC & (Zvonic et al., 2007) \\
\hline NM23/nucleoside diphosphate kinase & ADSC & (Zvonic et al., 2007) \\
\hline prohibitin & ESC, NSC & (Baharvand et al., 2007) \\
\hline prosaposin & ADSC & (Zvonic et al., 2007) \\
\hline putative cathepsin L & ADSC & (Zvonic et al., 2007) \\
\hline serum albumin B precursor & MSC, NSC & (Baharvand et al., 2007) \\
\hline $\begin{array}{l}\text { SWI/SNF related, matrix associated, actin- } \\
\text { dependent regulator of chromatin, } \\
\text { subfamily d, member } 1\end{array}$ & ESC & (van Hoof et al., 2007) \\
\hline transaldolase 1 & ADSC & (Zvonic et al., 2007) \\
\hline tropomyosin & MSC, NSC & (Baharvand et al., 2007) \\
\hline vimentin (VIM1, VIM4) & MSC, NSC & (Baharvand et al., 2007) \\
\hline
\end{tabular}

Protein names listed in bold type are those whose encoding gene was also found expressed at higher levels in stage $533 \mathrm{dPA}$ versus $1 \mathrm{dPA}$ (unpublished). $\mathrm{MSC}=$ mesenchymal stem cells; NSC $=$ neural stem cells; $E S C=$ embryonic stem cells; $A D S C=$ adipose tissue stem cells. 
by monoclonal antibody WE6. Estrada etal. (1993) localized WE6 expression in glands of newt skin and other mucosae, with weak staining in endothelium and smooth muscle. In limb blastemas KRT17 was strongly expressed in the wound epidermis but completely absent in underlying mesenchymal cells, and this same pattern of WE6 expression was also seen in amputated non-regenerating forelimbs of post-metamorphic Xenopus and Rana (Estrada et al., 1993).

In mammals KRT17 is also expressed in epidermal appendages (hair follicles, nail beds, sebaceous glands, and sweat glands, including myoepithelial cells) but in interfollicular keratinocytes only after acute injury or inflammation (McGowan and Coulombe, 1998). Kim et al. (2006) have shown that KRT17 regulates protein synthesis and cell growth during keratinocyte migration and epithelial wound closure, an effect mediated by mTOR kinase with binding of KRT17 to the adaptor protein 14-3$3 \sigma$. This work suggests that KRT17 and other intermediate filament proteins that provide modulated structural support during cell migration also influence cell growth and death through dynamic interactions with non-structural proteins (Coulombe and Wong, 2004).

Another keratin up-regulated in our study is KRT8, which has been previously shown by Ferretti to be transiently expressed in dedifferentiating mesenchymal cells 3-5 days after amputation in adult newt limbs (Corcoran and Ferretti, 1997). Although KRT8 is well-known to dimerize with KRT18 as part of the cytoskeleton in simple epithelial cells, it has also been found to associate with ANXA1, suggesting a role in modulation of the inflammatory response (Croxtall et al., 1998; Rual et al., 2005).

This proteomics study found increased levels of numerous inflammatory factors following amputation, which is consistent with the gene expression profiles of regenerating amphibian or fish appendages (Grow et al., 2006; Lien et al., 2006; Schebesta et al., 2006). These include annexins, anti-oxidant proteins, complement components, galectins, granulin, cathepsins, vimentin, and factors that regulate transforming growth factor- $\beta$ (TGF- $\beta$ ) signaling. Immunohistochemistry indicates that vimentin is localized primarily in scattered cells of stage 53 limbs and blastemas, particularly in Langerhans-like cells of the epidermis (Mescher et al., 2007). Up-regulation of many such inflammationrelated genes is greater in limbs of prometamorphic Xenopus at regeneration-incomplete stages than in limbs at stage 53, which regenerate well (Grow et al., 2006). One interpretation of these results is that the developmental state of the anuran immune system and the differentiation status and number of cells mediating the inflammatory response to trauma may determine the nature of the regenerative response to amputation (Harty et al., 2003; Mescher and Neff, 2005; Mescher and Neff, 2006), a hypothesis consistent with current work on scar formation after injury to developing mammalian skin (Martin and Leibovich, 2005).

Among the proteins showing a substantial increase three days after amputation at stage 53 are members of the annexin family, particularly ANXA1 and ANXA2, all of which were identified with multiple sequences. Annexins bind phospholipids in a $\mathrm{Ca}^{2+}$ dependent manner and help regulate a wide variety of cellular activities (Gerke and Moss, 2002). ANXA1, whose expression is up-regulated by glucocorticoids, is one of several anti-inflammatory mediators that operate locally to ensure the transient profile of the inflammatory reaction, i.e. to prevent chronic inflammation with its potential for tissue damage (Perretti and Flower, 2004). ANXA1 and ANXA2 lack signal peptides but can be exported to the cell surface or ECM in a dimeric complex with S100A10 (Svenningsson and Greengard, 2007) another protein found to be up-regulated at 3dPA (Table 2). Complexed with S100A10 on the cell surface, ANXA2 binds plasminogen and promotes other key effects during inflammation, including the localized generation of plasmin important for focused degradation of the ECM and cellular invasiveness (Kwon et al., 2005a); stimulates the release of the angiogenesis inhibitor angiostatin as plasminogen undergoes autoproteolytic cleavage (Kwon et al., 2005b); and triggers the plasmin-induced release of tissue factor (TF), IL-1, TNF- $\alpha$, monocyte chemoattractant protein-1, and other factors from monocytes (Laumonnier et al., 2006).

The important roles of ANXA1 and ANXA2 as highly localized anti-inflammatory factors make these proteins prime candidates not only in regulating local activities in the amputated limb but also in determining whether inflammation is short-lived or prolonged. ANXA2 expression is up-regulated during both tail (Tazaki et al., 2005) and limb (Grow et al., 2006) regeneration in larval Xenopus. The activity of the ANXA2-S100A10 heterotetramer in stimulating plasmin-induced expression of TF in activated monocytes (Laumonnier et al., 2006) may be important for the localized production of TF and thrombin required for initiating regeneration in both newt limbs (Morais da Silva et al., 2002) and lens (Godwin and Brockes, 2006; Imokawa and Brockes, 2003). Such studies add considerable interest to the ANXA2-S100A10 heterotetramer as an inflammatory component to be examined during regeneration.

We show here that expression of ANXA1, ANXA2, and S100A10 is up-regulated within one day after amputation in limbs of both stage 53 and stage 57 larvae (Figure 3). Expression of all three genes remains elevated 5 days post-amputation in limbs of stage 57 larvae, but declines during this period in limbs of stage 53 larvae, an expression pattern shared with several other inflammation-related genes (Grow et al., 2006). These results are consistent with the view that inflammation is prolonged in the "pseudoblastemas" of regeneration-incompetent limbs, but is resolved more quickly in the limb stumps of stage 53 larvae which regenerate almost completely. Taken together with evidence from mammalian studies (Perretti and Flower, 2004), it is highly suggestive of a role for ANXA1 in determining the course of inflammation and its resolution.

Microarray studies of mammalian wound healing and the use of transgenic or knockout models for specific leukocytes or cytokines have made increasingly clear that the inflammatory phase of repair determines the extent of scar formation or the quality of tissue regeneration (Harty et al., 2003; Cooper et al., 2005; Martin and Leibovich, 2005; Mescher and Neff, 2005; Eming etal., 2007). Such studies also reveal that activation of proinflammatory genes and cytokines is generally accompanied by activation of anti-inflammatory genes and expression of mediators which down-regulate aspects of the inflammatory response (Babbin and Gewirtz, 2005; Martin and Leibovich, 2005). The balance of activities between pro- and anti-inflammatory factors characterizes the normal sequence of inflammatory events, including recruitment of leukocytes, killing and removal of potential pathogenic invaders, and removal of dead tissue, followed by an 
active process of resolution that ends these activities (Ariel and Serhan, 2007). Circumstances which produce excessive or prolonged pro-inflammatory activity can lead to chronic wounds or excessive scarring. In addition to fetal skin, experimental manipulations that reduce the number of inflammatory cells, or signaling from certain mediators such as TGF- $\beta$ after wounding, lead to faster repair, reduced scarring, and possible restoration of normal tissue architecture (Harty et al., 2003; Martin and Leibovich, 2005).

Finally, since cells of the distal amputated limb stump undergo dedifferentiation and proliferate to form the regeneration blastema and, the relationship of blastema cells to stem cells is not clear, we also wished to determine whether any of the abundant proteins significantly up-regulated in 3dPA have been identified consistently in stem cells. Proteins listed in Table 2 were compared to those identified in mammalian stem cells primarily by proteomic analyses and recently reviewed by Baharvand et al. (2007) and others. As shown in Table 6 nearly thirty of the abundant proteins of various functional classes up-regulated during blastema formation are also expressed in a variety of cultured mammalian stem cells. Expression of these blastema proteins was most commonly shared with mesenchymal and adipose-derived stem cells. Eight of these proteins up-regulated in both blastema and stem cells have also been shown to have increased gene expression in limbs following amputation (Grow et al., 2006). Table 6 only includes proteins from categories 1 and 2 that are significantly up-regulated 3 days after amputation; proteins in category 3 (identified from multiple peptides with a confidence of $75-89 \%$ ) include several others with expression shared by stem cells, including Tpt1 (translationally controlled tumor protein-1, TCTP), which was recently found to be an activator of the oct4 and nanog pluripotency transcription factors during reprogramming of transplanted somatic nuclei in Xenopus eggs (Koziel et al., 2007). Further analysis of proteins expressed in both the blastema and multiple stem cells should yield insights into the nature of cellular dedifferentiation in the limb stump and the possible involvement of stem cells in limb regeneration.

This proteomic study, together with the screens of gene expression during early regeneration, reveals that both pro-inflammatory and anti-inflammatory activities are up-regulated in amputated amphibian limb stumps. This raises the likelihood that ideas emerging from recent work on mammalian wound healing regarding the control of scarring and tissue regeneration will prove applicable to limb regeneration and will yield greater understanding of the ontogenic decline of regeneration in anurans. Together with comparisons of proteomic and gene array analyses of stem cells, further work on the role of inflammation during the early phase of regeneration will yield additional insights into the molecular bases of dedifferentiation and other aspects of epimorphic regeneration.

\section{Materials and Methods}

\section{Limb amputation and blastema collection}

Larval Xenopus laevis were raised in the laboratory or obtained commercially (NASCO, Ft. Atkinson, WI.) and hindlimbs were staged according to Nieuwkoop and Faber (1967). All surgical procedures were performed according to procedures approved by the Indiana University Animal Care and Use Committee following anesthesia in $0.005 \%$ benzocaine. Hindlimbs at stage 53 (when regeneration is essentially com- plete) were amputated bilaterally at the mid-zeugopodia. Immediately (OdPA) and 3 days (3dPA) after amputation, tissues were collected $1 \mathrm{~mm}$ proximal to the original plane of amputation and pooled for proteomic analysis.

\section{Tissue preparation, LC/MS/MS and data analysis}

All processing of tissues, mass spectrometry and statistical analysis of data was carried out under contract with Monarch Life Sciences, LLC (Indianapolis, IN.), formerly the Indiana Centers for Applied Protein Science (INCAPS), a fee-for-service contract research company formed through Indiana University, Eli Lilly \& Co, and other organizations. A total of 10 pools of tissue each from 0dPA and 3dPA limbs stumps was collected and processed for protein digestion. Each pool of tissue consisted of 120 hindlimb or blastema pieces. Tissues were homogenized and the resultant lysates were reduced and alkylated by triethylphosphine and iodoethanol and then digested with trypsin as described (Higgs et al., 2005 and 2007). Peptide concentration in each pool was determined by the Bradford protein assay. All procedures for quantification of proteins, assurance of quality of the results and statistical analysis were carried out according to the detailed steps outlined by Fitzpatrick et al. (2007) and Monarch Life Sciences, LLC. Details of the Methods used in this publication are included as supplementary materials.

\section{Reverse-transcription and quantitative PCR ( $P P C R$ )}

Analysis of the expression of several annexin genes and S100A10 was carried out using quantitative RT-PCR essentially as described by King etal. (1998). Total RNA samples were extracted using the RNAqueous Micro system (Ambion, USA). Reverse transcription reactions were carried out using $1 \mu \mathrm{g}$ of total RNA purified from indicated sources. Each qPCR was carried out using the equivalent of $2.8 \mathrm{ng}$ of input RNA. As a control for RNA loading into the RT reaction, expression of Xenopus laevis ornithine decarboxylase (ODC) was assayed (King et al., 1998). The primer sequences are: ANXA1 (accession BC053786) upstream: 5'cagatctgcattcagtccttgatc-3', downstream: 5'-gcttgcctacgctctttggtaag-3', ANXA2 (accession M60768) upstream: 5'-ggaaatcaatcatgtgcaaggcag-3' downstream: 5'-tttccagattgccagaaagcgctc-3'; S100A10 (accession M538593) upstream: 5'-tgcaacgagtattacgtcaaacac-3', downstream: 5'atggagggtaaatctggaatagag-3'.

Quantitative PCR was performed utilizing the Mx3000P QPCR System (Stratagene, USA.). Fluorescence detection chemistry involved utilization of SYBR green dye master mix (Bio Rad, USA.) and was carried out as described (Grow et al., 2006). Each RT reaction was equalized for RNA input by assessing the level of expression of the relatively invariant housekeeping gene ornithine decarboxylase (ODC) and quantitative expression of each gene of interest was then normalized to the level of ODC.

\section{Acknowledgements}

This work was supported by a pilot grant from the Indiana University School of Medicine to MWK and the Indiana 21st Century Technology and Developmental Fund. The authors would like to thank Drs. Mu Wang, Kerry Bemis and Jin-Sam You of Monarch Life Sciences for their invaluable help with data acquisition. The authors are indebted to Randy J. Arnold, Department of Chemistry, Indiana University, for critical interpretation of our proteomics data. The authors wish to thank Betsy Osborne for expert technical assistance.

\section{References}

ABBAS, A. R., et al. (2005). Immune response in silico (IRIS): immune-specific genes identified from a compendium of microarray expression data. Genes Immunity. 6: 319-331.

ARIEL, A., and SERHAN, C. N., (2007). Resolvins and protectins in the termination program of acute inflammation. Trends Immunol. 28: 176-183.

BABBIN, B. A., and GEWIRTZ, A. T., (2005). A most important annexation. Am. J. 
Pathol. 166: 1581-1583.

BAHARVAND, H., et al. (2007). Concise review: Trends in stem cell proteomics. Stem Cells. 25: 1888-1903.

BENES, P., et al. (2006). Role of vimentin in regulation of monocyte/macrophage differentiation. Differentiation. 74: 265-76.

BROWN, D. P. G., et al. (2007). A comparative proteomic study to characterize the vinblastine resistance in human ovarian cancer cells. Proteomics Clin. Appl. 1: 18-31.

CHILDS, K. S., and GOODBOURN, S., (2003). Identification of novel co-repressor molecules for Interferon Regulatory Factor-2. Nucleic Acids Res. 31: 3016-26.

COOPER, L., et al. (2005). Wound healing and inflammation genes revealed by array analysis of 'macrophageless' PU.1 null mice. Genome Biol. 6.

CORCORAN, J. P., and FERRETTI, P., (1997). Keratin 8 and 18 expression in mesenchymal progenitor cells of regenerating limbs is associated with cell proliferation and differentiation.' Dev. Dyn. 210: 355-370.

COULOMBE, P. A., and WONG, P., (2004). Cytoplasmic intermediate filaments revealed as dynamic and multipurpose scaffolds. Nat. Cell Biol. 6: 699-706.

CROXTALL, J. D., et al.,1998). Lipocortin 1 co-associates with cytokeratins 8 and 18 in A549 cells via the N-terminal domain. Biochim Biophys Acta-Mo/Cel/ Res. 1401: 39-51.

EMING, S. A., et al. (2007). Inflammation in wound repair: Molecular and cellular mechanisms. J. Invest. Dermatol. 127: 514-525.

ESTRADA, C. M., et al., (1993) Monoclonal antibody WE6 identified an antigen thatb is up-regulated in the wound epithelium of newts and frogs. In Limb Development and Regeneration, Part $A$ (Eds. J.F. Fallon, et al.) . Wiley-Liss, Inc., New York. pp. 271-282.

FITZPATRICK, D. P. G., et al. (2007). Searching for potential biomarkers of cisplatin resistance in human overian cancer using a label-free LC/MS-based protein qualtification method. Proteomics - Clinical Applications. 1: 246-263.

GERAUDIE, J., and FERRETTI, P., (1998). Gene expression during amphibian limb regeneration. Int. Rev. Cytol. 180: 1-50.

GERKE, V., MOSS, S. E., (2002). Annexins: From structure to function. Physiol. Rev. 82: 331-371.

GODWIN, J. W., and BROCKES, J. P., (2006). Regeneration, tissue injury and the immune response. J. Anat. 209: 423-432.

GROW, M. W., et al. (2006). Global analysis of gene expression in Xenopus limbs during stage-dependent complete and incomplete regeneration. Dev. Dyn. 235: 2667-2685.

HARTY, M., et al. (2003). Regeneration or scarring: An immunologic perspective. Dev. Dyn. 226: 268-279

HIGGS, R. E., et al. (2007). Estimating the statistical significance of peptide identifications from shotgun proteomics experiments. J. Proteome Res. 6: 1758-1767.

HIGGS, R. E., et al. (2005). Comprehensive label-free method for the relative quantification of proteins from biological samples. J. Proteome Res. 4: 14421450

HORWITZ, M. S., et al. (2007). Neutrophil elastase in cyclic and severe congenital neutropenia. Blood. 109: 1817-1824.

IMOKAWA, Y., and BROCKES, J. P., (2003). Selective activation of thrombin is a critical determinant for vertebrate lens regeneration. Curr. Biol. 13: 877-881.

IMOKAWA, Y., et al. (2004). Distinctive expression Myf5 in relation to differentation and plasticity of newt muscle cells. Int. J. Dev. Biol. 48: 285-291.

ISHINO, T., et al. (2003). Identification of genes induced in regenerating Xenopus tadpole tails by using the differential display method. Dev. Dyn. 226: 317-325.

KATOGI, R., et al. (2004). Large-scale analysis of the genes involved in fin regeneration and blastema formation in the medaka, Oryzias latipes. Mech. Dev. 121: 861-872.

KIM, S., et al. (2006). A keratin cytoskeletal protein regulates protein synthesis and epithelial cell growth. Nature. 441: 362-365.

KIMURA, Y., et al. (2003). Expression of complement 3 and complement 5 in newt limb and lens regeneration. J. Immunol. 170: 2331-2339.

KING, M. W., et al.,1998). Anterior structural defects by misexpression of Xgbx-2 in early Xenopus embryos are associated with altered expression of cell adhesion molecules. Dev. Dyn. 212: 563-579.
KING, M. W., et al. (2003). Identification of genes expressed during Xenopus laevis limb regeneration by using subtractive hybridization. Dev. Dyn. 226: 398-409.

KOZIEL, M. J., et al. (2007). Tpt1 activates transcription of oct4 and nanog in transplanted somatic nuclei. Curr. Biol. 17: 801-807.

KUMAR, A., et al. (2004). The regenerative plasticity of isolated urodele myofibers and its dependence on Msx1. PLOS Biol. 2: 1168-1176.

KWON, M., et al. (2005a). S100A10, annexin A2, and annexin A2 heterotetramer as candidate plasminogen receptors. Front. Biosci. 10: 300-325.

KWON, M., et al. (2005b). Annexin A2-S100A10 heterotetramer, a novel substrate of thioredoxin. J. Biol. Chem. 280: 23584-23592.

LAUMONNIER, Y., et al. (2006). Identification of the annexin A2 heterotetramer as a receptor for the plasmin-induced signaling in human peripheral monocytes. Blood. 107: 3342-3349.

LIEN, C. L., etal. (2006). Gene expression analysis of zebrafish heart regeneration. PLOS Biol. 4: 1386-1396.

LIU, N. K., et al. (2007). Annexin A1 reduces inflammatory reaction and tissue damage through inhibition of phospholipase A(2) activation in adult rats following spinal cord injury. J. Neuropathol. Exp. Neurol. 66: 932-943.

MARTIN, P., and LEIBOVICH, S. J., (2005). Inflammatory cells during wound repair: the good, the bad, and the ugly. Trends Cel/ Biol. 15: 599-607.

MATSUMOTO, S., et al. (2006). Brg1 is required for murine neural stem cell maintenance and gliogenesis. Dev. Biol. 289: 372-83.

MCGOWAN, K. M., and COULOMBE, P. A., (1998). Onset of keratin 17 expression coincides with the definition of major epithelial lineages during skin development. J. Cell Biol. 143: 469-486.

MESCHER, A. L., and NEFF, A. W., Regenerative capacity and the developing immune system. Regenerative Medicine I: Theories, Models and Methods, Vol. 93, 2005, pp. 39-66.

MESCHER, A. L., and NEFF, A. W., (2006). Limb regeneration in amphibians: Immunological considerations. ScientificWorldJournal. 6: 1-11.

MESCHER, A. L., et al. (2007). Cells of cutaneous immunity in Xenopus: Studies during larval development and limb regeneration. Dev. Comp. Immunol. 31: 383-393.

MITULOVIC, G., and MECHTLER, K., (2006). HPLC techniques for proteomics analysis - a short overview of latest developments. Brief. Funct. Genomic. Proteomic. 5: 249-260.

MONAGHAN, J. R., et al. (2007). Early gene expression during natural spinal cord regeneration in the salamander Ambystoma mexicanum. J. Neurochem. 101 $27-40$

MORAIS DA SILVA, S., et al. (2002). The newt ortholog of CD59 is implicated in proximodistal identity during amphibian limb regeneration. Dev. Cell. 3: 547555.

MOSESSON, M. W., et al. (2001). The structure and biological features of fibrinogen and fibrin. Fibrinogen (Ann NY Acad Sci). 936: 11-30.

MUNOZ, L. E., et al. (2007). The role of annexin A5 in the modulation of the immune response against dying and dead cells. Current Med. Chemistry. 14: 271-277.

NIEUWKOOP, P., and FABER, J., 1967. Normal Table of Xenopus laevis (Daudin). North-Holland, Amsterdam.

ONG, C. H., et al. (2006). Regulation of progranulin expression in myeloid cells Amer Jour Physiol - Reg Integ Comp Physiol. 291: R1602-12.

PARENTE, L., SOLITO, E., (2004). Annexin 1: more than an anti-phospholipase protein. Inflamm. Res. 53: 125-132.

PERI, S., et al. (2003). Development of human protein reference database as an initial platform for approaching systems biology in humans. Genome Res. 13: 2363-2371.

PERRETTI, M., and FLOWER, R., (2004). Annexin 1 and the biology of the neutrophil. J. Leukoc. Biol. 75: 25-29.

PUTTA, S., et al. (2004). From biomedicine to natural history research: EST resources for ambystomatid salamanders. BMC Genomics. 5 .

RUAL, J. F., et al. (2005). Towards a proteome-scale map of the human proteinprotein interaction network. Nature. 437: 1173-1178.

RUTGERS, A., et al. (2003). The role of myeloperoxidase in the pathogenesis of systemic vasculitis. Clin. Exp. Rheumatol. 21: S55-63.

SCANNELL, M., et al. (2007). Annexin-1 and peptide derivatives are released by 
apoptotic cells and stimulate phagocytosis of apoptotic neutrophils by macrophages. J. Immunol. 178: 4595-4605.

SCHEBESTA, M., et al. (2006). Transcriptional profiling of caudal fin regeneration in zebrafish. ScientificWorldJournal. 6: 38-54.

SCHOELER, D., et al. (2003). Interleukin-6 enhances whereas tumor necrosis factor alpha and interferons inhibit integrin expression and adhesion of human mast cells to extracellular matrix proteins. J. Invest. Dermatol. 120: 795-801.

SOLITO, E., et al. (2008). Annexin A1 in the brain-undiscovered roles? Trends Pharmacol. Sci. 29: 135-142.

STOCUM, D. L., 2006. Regenerative Biology and Medicine. Academic Press, Oxford.

SVENNINGSSON, P., and GREENGARD, P., (2007). p11 (S100A10) - an inducible adaptor protein that modulates neuronal functions. Curr. Opin. Pharmacol. 7: 27-32.

TASSAVA, R. A., and LOYD, R. M., (1977). Injury requirement for initiation of regeneration of newt limbs which have whole skin-grafts. Nature. 268: 49-50.

TASSAVA, R. A., and MESCHER, A. L., (1975). Roles of injury, nerves, and wound epidermis during initiation of amphibian limb regeneration. Differentiation. 4: 23-24.
TAZAKI, A., et al. (2005). Macroarray-based analysis of tail regeneration in Xenopus laevis larvae. Dev. Dyn. 233: 1394-1404.

THEISS, A. L., et al. (2007). Interleukin-6 and tumor necrosis factor alpha inversely regulate prohibitin expression in intestinal epithelial cells. Gastroenterology. 132: A569-A569.

TSONIS, P. A., et al.,1992). Protein synthesis in the newt regenerating limb:comparative 2-dimensional PAGE, computer analysis and protein sequencing. Biochem. J. 281: 665-668.

UGAROVA, T. P., and YAKUBENKO, V. P., (2001). Recognition of fibrinogen by leukocyte integrins. Fibrinogen (Ann NY Acad Sci). 936: 368-385.

VAN HOOF, D., et al. (2007). Embryonic stem cell proteomics. Expert Rev. Proteomics. 3: 427-37.

WEINBERG, E. D., (2007). Antibiotic properties and applications of lactoferrin. Curr. Pharm. Des. 13: 801-811.

WU, C. C., et al.,1995). LIPOCORTIN-1 MEDIATES THE INHIBITION BY DEXAMETHASONE OF THE INDUCTION BY ENDOTOXIN OF NITRIC-OXIDE SYNTHASE IN THE RAT. Proc. Natl. Acad. Sci. U. S. A. 92: 3473-3477.

ZVONIC, S., etal. (2007). Secretome of primary cultures of human adipose-derived stem cells - Modulation of serpins by adipogenesis. Mol. Cell. Proteomics. 6: 18 28. 


\section{Further Related Reading, published previously in the Int. J. Dev. Biol.}

See our recent Special Issue Fertilization, in honor of David L. Garbers and edited by Paul M. Wassarman and Victor D. Vacquier at: http://www.ijdb.ehu.es/web/contents.php?vol=52\&issue=5-6

See our Special Issue Limb Development, edited by Juan Hurlé and Juan Carlos Izpisua-Belmonte at:

http://www.ijdb.ehu.es/web/contents.php?vol=46\&issue $=7$

Planarian regeneration: achievements and future directions after 20 years of research

Emili Saló, Josep F. Abril, Teresa Adell, Francesc Cebriá, Kay Eckelt, Enrique Fernández-Taboada, Mette Handberg-Thorsager, Marta Iglesias, M Dolores Molina and Gustavo Rodríguez-Esteban

Int. J. Dev. Biol. (2008) 52: doi: 10.1387/ijdb.072414es

Distinct patterns of MMP-9 and MMP-2 activity in slow and fast twitch skeletal muscle regeneration in vivo

Malgorzata Zimowska, Edyta Brzoska, Marta Swierczynska, Wladyslawa Streminska and Jerzy Moraczewski

Int. J. Dev. Biol. (2008) 52: 307-314

From Planarians to Mammals - the many faces of regeneration

Jerzy Moraczewski, Karolina Archacka, Edyta Brzoska, Maria-Anna Ciemerych, Iwona Grabowska, Katarzyna Janczyk-llach, Wladyslawa Streminska and Malgorzata

Zimowska

Int. J. Dev. Biol. (2008) 52: 219-227

Role of Jun N-terminal Kinase (JNK) signaling in the wound healing and regeneration of a Drosophila melanogaster wing imaginal disc

Jaakko Mattila, Leonid Omelyanchuk, Satu Kyttälä, Heikki Turunen and Seppo

Nokkala

Int. J. Dev. Biol. (2005) 49: 391-399

FGF signalling and blastema growth during amphibian tail regeneration

P Ferretti, F Zhang, L Santos-Ruiz, JDW Clarke

Int. J. Dev. Biol. (2001) 45: S127-S128

Differential expression of FGF receptors during zebrafish fin regeneration L Santos-Ruiz, JA Santamaria, J Becerra

Int. J. Dev. Biol. (2001) 45: S131-S132

The cellular basis of limb regeneration in urodeles.

A L Mescher

Int. J. Dev. Biol. (1996) 40: 785-795

Patterns of dystrophin expression in developing, adult and regenerating tail skeletal muscle of Amphibian urodeles.

J P Arsanto, $X$ Caubit, E Fabbrizio, J Léger, D Mornet and $Y$ Thouveny

Int. J. Dev. Biol. (1992) 36: 555-565

Formation of the extracellular matrix during the epimorphic anterior regeneration of Owenia fusiformis: autoradiographical and in situ hybridization studies.

F Dupin, J Coulon, Y Le Parco, M Fontes and $Y$ Thouveny

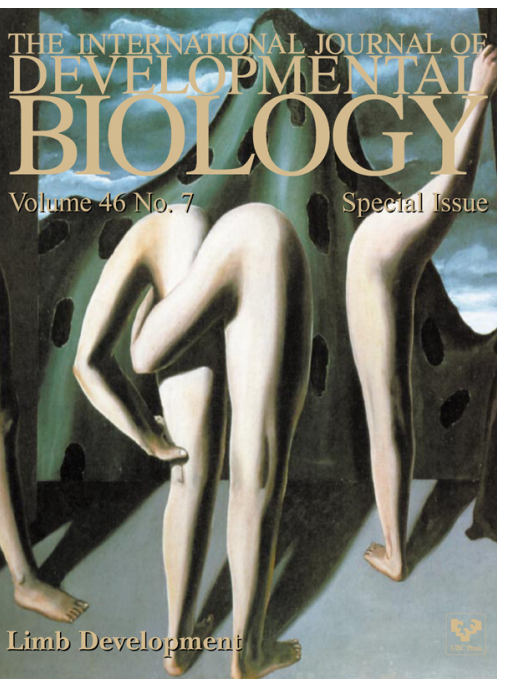

5 yr ISI Impact Factor $(2008)=3.271$

Int. J. Dev. Biol. (1991) 35: 109-119

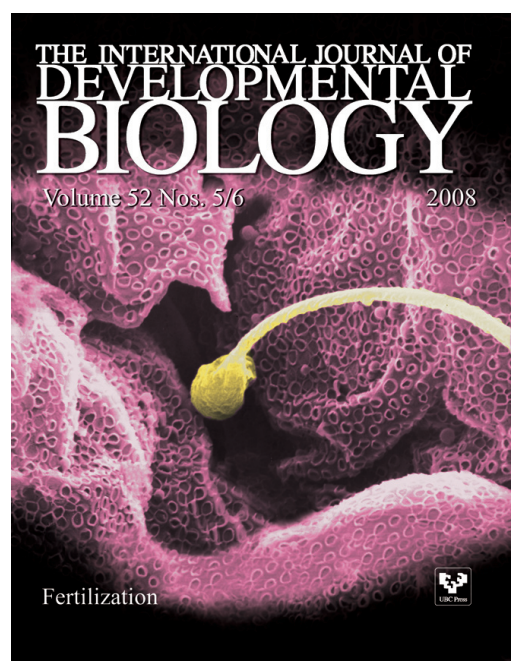

